\title{
VARIABILITY OF SEA-FLOOR ROUGHNESS WITHIN THE COASTAL OCEAN DYNAMICS EXPERIMENT (CODE) REGION
}

by

David A. Cacchione,* David E. Drake,*

William D. Grant,** Albert J. Williams, III,** and George B. Tate,*

* U.S. Geological Survey, Menlo Park, CA 94040

** Woods Hole Oceanographic Institution, Woods Hole, MA 02543

\section{WOODS HOLE OCEANOGRAPHIC INSTITUTION}

Woods Hole, Massachusetts 02543

August 1983

WHOI Technical Report 83-25

CODE Technical Report No. 16

Funding was provided by the National Science Foundation under Grant OCE 80-14938 and OCE 80-14941 and by the United States Geological Survey.

Reproduction in whole or in part is permitted for any purpose of the United States Government. This report should be cited as: Woods Hole Oceanog. Inst. Tech. Rept. WHOI-83-25.

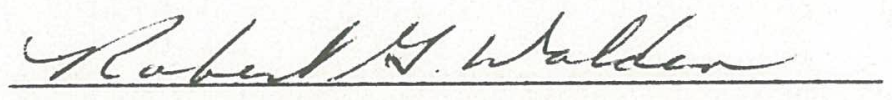

Robert G. Walden, Acting Department Chairman Department of Ocean Engineering

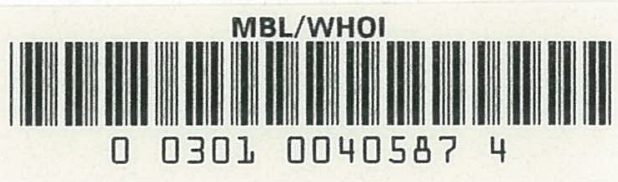




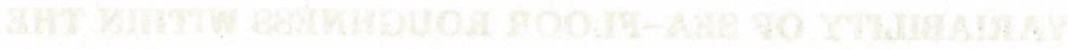

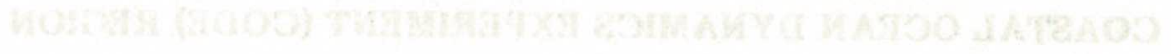


TABLE OF CONTENTS

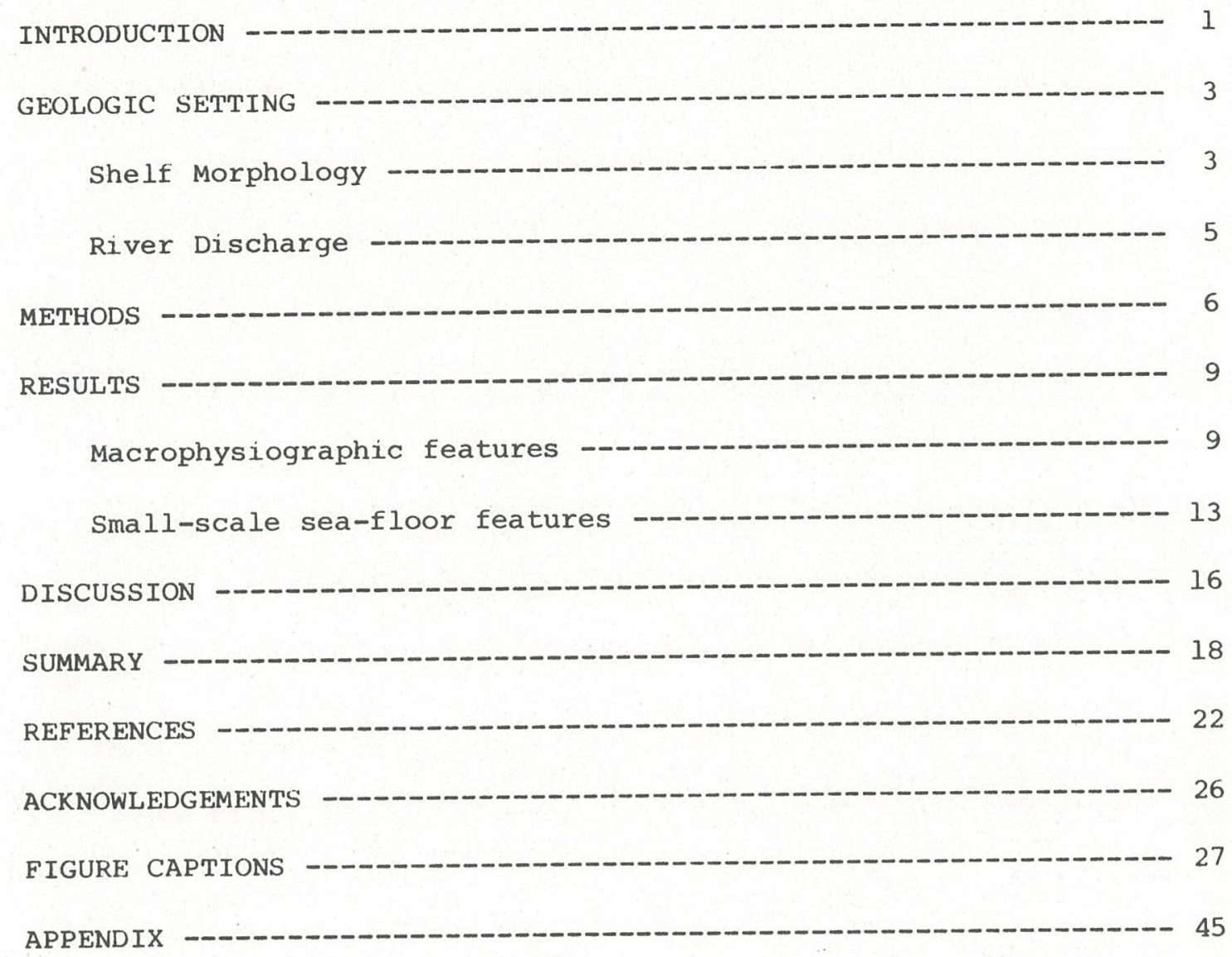


This report briefly summarizes the geological and biological data taken off northern California before and during the Coastal Ocean Dynamics Experiment (CODE) (Allen et al, 1982) by the principal investigators of the bottom stress/bottom boundary layer component of CODE (D. Cacchione, D. Drake, USGS; and W. Grant, A. Williams, WHOI) and other cooperating investigators of the U.S. Geological Survey. In these experiments either a single tripod or an array of tripods was placed on the sea floor to obtain measurements of the local vertical profile of horizontal velocity and in some cases, also the stress. The findings reported here concentrate on a description of sea floor relief that likely influences the near-bottom flow field at the CODE site, and that significantly affects our ability to make bottom stress estimates from theoretical computations. The report describes the general physical characteristics of the CODE site, the macro- and micro- physiography, sediment distribution and discharge of the larger coastal rivers.

Geological features on the continental shelf influence the near-bottom flow field over a wide range of scales. At the largest scales the width and bottom gradient of the continental shelf influence the propagation of internal and surface waves. These waves affect the bottom stress on the continental shelf in several ways: (1) interaction with mean flows (Grant and Madsen, 1979; Smith, 1977; Cacchione and Drake, 1982; Grant and Glenn, in press); (2) distortion of near-bottom velocity profiles (Grant, 1982); and (3) sediment transport effects associated with bedform generation, near-bed transport (Grant and Madsen, 1982) and suspended sediment induced stratification (Smith, 1977; Glenn, 1983; Grant and Glenn, in press). As surface waves shoal across the sloping shelf seafloor, their interaction with the bottom flow field and 
bottom sediment intensifies. The intensification results in cross-shelf gradients in bottom stress which influence the magnitude and phase of the longshore coastal flow.

On smaller scales, on the order of tens of meters, individual features of the shelf topography may act as isolated roughness elements which dissipate energy through form drag, and therefore contribute to the total momentum balance on the shelf. These same elements, when in relatively dense concentrations, may also steer the near bottom flow.

At the smallest scales ( $<1$ meter), most of the topography on the shelf is controlled through complex interactions between waves, currents, sediment and benthic biota. At the largest scales in this range, bedforms develop through instabilities at the seawater - sediment interface. Bedforms occur at scales of a meter to centimeters depending on the sediment type, boundary shear stress and biological reworking of the sediments. Mounds and furrows created by benthic biota are also prevalent at scales on the order of centimeters.

Other biogenic effects important to destabilizing or stabilizing the sediment occur through biological reworking of the surficial sediment or adhesion induced by mucus secretions, respectively (Rhoads et al, 1978; Grant et al, 1982; Nowell, et al, 1981). Under flow conditions where ripples would normally form in abiotic sediments, biologically induced adhesion may prevent bedload transport, and the bed may remain smooth.

During storm conditions, large amounts of resuspended sediment can stably stratify the flow, thus influencing vertical momentum transport, the shape of the near bottom velocity profile and the boundary shear stress (Smith and Mclean, 1977; Grant and Glenn, in press). The potential for stratification is 
dependent upon the grain size and density of the sediment, and the sediment concentration.

The preceeding brief summary of some of the major considerations on sedimentological and physiological features of the continental shelf hopefully provides insight into the motivation for the effort that led to the results reported here, and to the biases in reporting these results in the present format.

\section{GEOLOGIC SETTING}

\section{Shelf Morphology}

The orientations of the shelf break, the coastline, and the major onshore topographic elements from point Arena to Bodega Bay parallel the nearly linear trend of the San Andreas fault and its associated faults and folds (Fig. l). From Point Arena to near the Russian River, the San Andreas fault, the coastline and the shelf isobaths vary little from a trend of about $320^{\circ} \mathrm{T}$. Coastal uplift associated with the active fault systems has produced a relatively narrow shelf $(20-30 \mathrm{~km})$ backed principally by $10-20 \mathrm{~m}$ high cliffs and the rugged coast Range mountains. Whereas the average trend of the coastline deviates little from the regional structural trend $\left(320^{\circ} \mathrm{T}\right)$, on a smaller scale the coast is characterized by numerous rocky promontories, submerged rock ledges, and small pocket beaches. Even in the vicinity of the Russian River the supply of sand is not large enough to form stable, continuous beaches which would protect the shore from intensive wave erosion. The shelf surface exhibits significant cross-shelf and along-shelf changes in topography and sediment types. Shore-normal, high-resolution seismic lines typically cross three distinctive zones (Fig. 2): 
1. An "inner shelf" zone extending to depths of about $60-70 \mathrm{~m}$. In this zone the bottom slope ranges from $1^{\circ}$ to $2^{\circ}$ and is covered by fine-to coarse-grained sands. The "shoreface" sand body is about 5-10 m thick in the northern part of the area and increases to $20-30 \mathrm{~m}$ near the Russian River. From the shore to depths of about $30-40 \mathrm{~m}$ the sand "wedge" is commonly broken by submerged rock ledges that may rise several meters above the surrounding sea floor. The roughly shorenormal rock ledges (which are more common toward Point Arena owing to a reduced sediment cover) probably act as natural groins.

2. The inner shelf zone merges rather abruptly with the "central shelf" zone which extends from $60-70 \mathrm{~m}$ to about $120-140 \mathrm{~m}$. The average bottom slope in this zone is about $0.3^{\circ}$, and from the latitude of Saunders Reef ("North line") to Bodega Head, the largest bottom roughness elements are measured in centimeters and are primarily produced by the benthonic organisms. The sedimentary deposits on the central shelf are principally sandy silts contributed by the Russian River. Consequently, the thickness of the sediment blanket increases toward the river, and the smoothing effects of mud deposition are more evident on the southern part of the shelf.

3. The modern sediment cover thins to less than $0.5 \mathrm{~m}$ at depths exceeding 120-130 m, and the central shelf "mud belt" gives way to an "outer shelf" zone characterized by thin and irregular patches of modern and relict sediment mixtures. Steeply-dipping Tertiary formations and massive Mesozoic granodiorite bodies are typically located beneath the thin sediment cover at the outer shelf, and the bedrock commonly crops 
out to form low (perhaps $1-3 \mathrm{~m}$ high) rocky areas (Fig 2A). The seismic data on the outer shelf along the "North line" show rock outcrops, and D. Klise (1983) has mapped quite extensive areas of exposed rock on the upper slope and outer shelf near and to the south of the CODE Central Line (line C-C' in Fig. 1). It is likely, therefore, that the sea floor for a few kilometers on either side of the shelf break is characterized by locally rugged topography and a thin $(0-2 \mathrm{~m})$ veneer of unconsolidated sediments that contain a large proportion of relict sand (and perhaps even gravel).

\section{River Discharge}

The significant streams in the CODE area are the Gualala and Russian Rivers (Fig. 1). Both streams drain the coastal mountains, and their discharges are a direct function of local rainfall; there is no significant winter snow accumulation in the drainage basin. The local climate is of the "wet winter-dry summer", Mediterranean type. Generally, large fractions of annual stream discharge are produced by a small number of cyclonic winter storms. Because of this storm dependence the water discharge may vary by an order of magnitude from one year to the next.

The peak discharge period for the Russian River (and also the Gualala) is December-March, and by late April discharge usually decreases to about $100 \mathrm{~m}^{3} / \mathrm{s}$. The discharge remains low throughout the spring, summer and fall. Figures $3 a$ and $3 b$ show the discharge curves for the Russian River during 1 October 1980 to $12 \mathrm{July} \mathrm{1982.} \mathrm{Discharge} \mathrm{during} \mathrm{the} \mathrm{winter} \mathrm{of} \mathrm{1980-81}$ reflected the slightly below average amounts of rainfall for that season, whereas the discharge for 1981-82 was about twice the long-term mean owing to record rainfall. The 1981-82 season also included "late" storms in April 
which produced river discharges that rivaled the earlier, well-publicized destructive floods in December 1981. In fact, the mean daily discharge for April 1982 was $12,730 \mathrm{cfs}$, the highest for the 1981-82 "water year" exceeding the December mean by 1150 cfs. Groundwater maintained relatively high (200500 cfs) discharge rates through June and July 1982. The Gualala River is not gauged but, based on its drainage area, its annual discharge is probably about 10-20\% of the discharge of the Russian River.

\section{METHODS}

Geological and biological data were collected on two cruises during CODE-l and on three cruises during CODE-2. Table 1 summarizes those cruises which provided geological and biological data for this report. Note that several data-gathering efforts preceded CODE-1 ("pre-CODE"), and that the type and quantity of data provide an excellent basis for a description of the geological setting in this region.

High resolution seismic profiling, principally using $3.5 \mathrm{kHz}$ systems, revealed the sub-bottom geological structures to depths of several tens of meters below the sea floor. The $3.5 \mathrm{kHz}$ profiles, together with the $12 \mathrm{kHz}$ fathometer data, provide information on macrophysiographic variability including gradient of the shelf surface and distribution of rock outcrops and ledges. The latter features are also observed in the side-scan sonar records. Both wet- and dry-paper recording systems were used in the side-scan sonar work during CODE. Sea-floor features having vertical relief larger than about $15 \mathrm{~cm}$ and lateral extents of at least $50 \mathrm{~cm}$ were resolved with these 


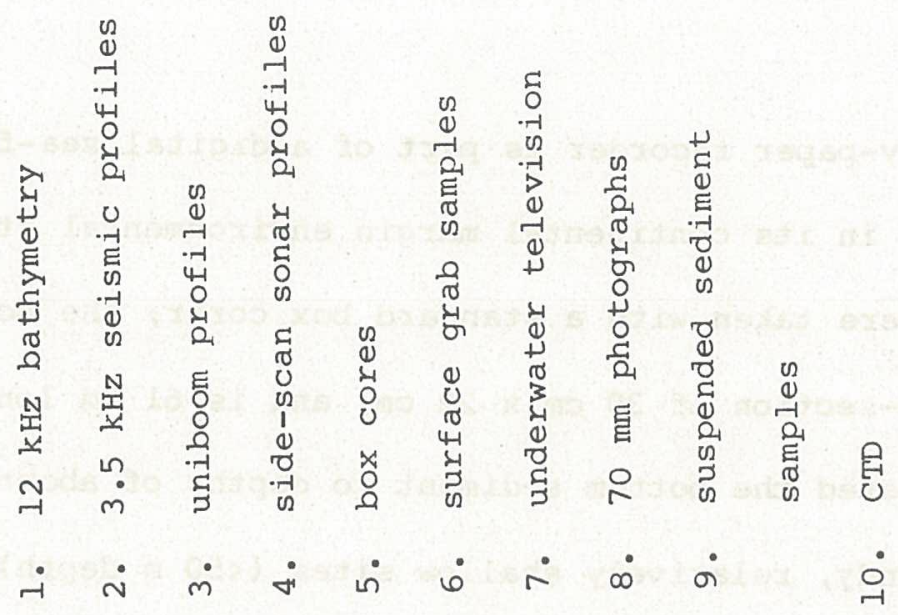

동

0

ฮั

in

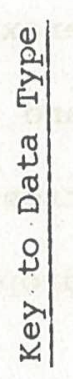

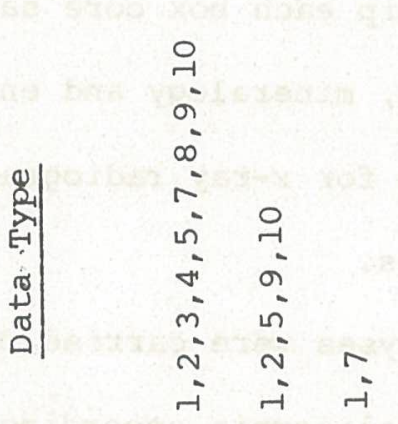

告|
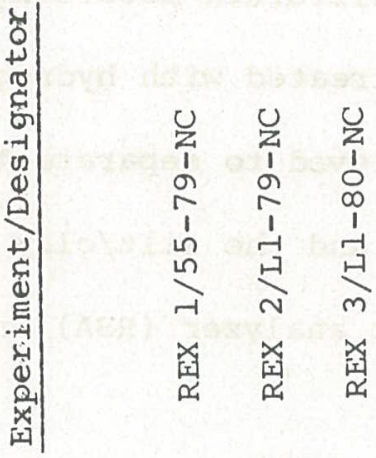

$\stackrel{-1}{\circ}$

के

$\infty \quad$ 응

in 우 우

i $ं$ वे गं अं

i

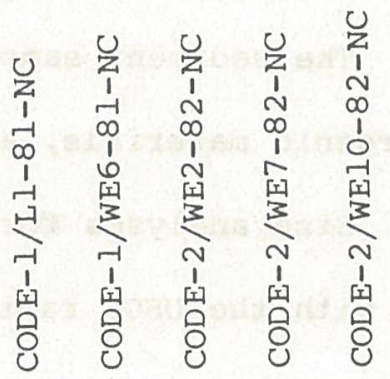

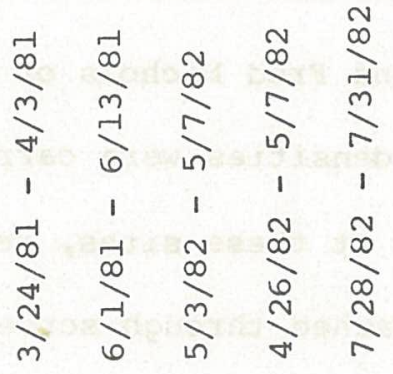

엠 
systems. The dry-paper recorder is part of a digital sea-floor mapping system used by the USGS in its continental margin environmental studies.

Box cores were taken with a standard box corer; the box sampler has a horizontal cross-section of $30 \mathrm{~cm} \times 22 \mathrm{~cm}$, and is $61 \mathrm{~cm}$ long. The box cores typically penetrated the bottom sediment to depths of about 50 to $60 \mathrm{~cm}$, except at the sandy, relatively shallow sites ( $<50 \mathrm{~m}$ depth) where shorter cores were usually obtained. On the ship each box core sample was subsampled for later laboratory studies of texture, mineralogy and engineering properties, and then slabbed vertically for $x$-ray radiographic analysis of primary and biogenic internal structures.

The textural and radiographic analyses were carried out at the marine sediment laboratory, USGS, Palo Alto, California according to established procedures. The sediment samples were treated with hydrogen peroxide solution to remove organic materials, and then sieved to separate the sand and finer components. Size analyses for the sand and the silt/clay fractions were carried out with the USGS rapid sediment analyzer (RSA) and hydrophotometer, respectively.

Epifauna and infauna were identified on selected box core samples by Jan McHendrie and Fred Nichols of the USGS. Quantitative studies of organism population densities were carried out on samples from several CODE mooring locations. At these sites, replicate box core samples (typically 3) were taken and washed through screens on deck to obtain macroorganism samples. In addition to the box cores, time-sequenced bottom photographs were taken with a $35 \mathrm{~mm}$ camera system mounted on an instrumended bottom tripod, GEOPROBE. The photographs provided information on temporal organism activity at Cl, C3, C4 and the experimental sites west of the Russian River (REX sites). Video tapes 
of underwater television recordings obtained during REX 3 (Table 1) were also used to identify epifaunal communities.

\section{RESULTS}

The continental shelf between the Russian River and the southern side of Pt. Arena covers about $1.6 \times 10^{3} \mathrm{~km}^{2}$ surface area. This surface, although characterized by rocky extensions of the rugged coastline into shallow water, is relatively flat-lying with very few features of significant relief from about 60 meters depth to the outer shelf. The shelf narrows and the regional bottom slope increases from the southern to the northern boundary (Table 2 ). The average bottom gradient is about 0.004 ; the average width is about $20 \mathrm{~km}$.

Table 2. Shelf Physiography - CODE region

Coastal. Location

Russian River

Stewart's Point

Fish Rock

Southern Pt. Arena

$$
\text { Shelf width }(\mathrm{km}) * * \frac{\text { Shelf Gradient** }}{\left(x 10^{3}\right)}
$$

28.0

$3 \cdot 3$

19.7

$5 \cdot 4$

17.4

6.0

$15 \cdot 4$

6.6

* Measured normal to bathymetry from $10 \mathrm{~m}$ to $150 \mathrm{~m}$ water depth. ** Determined for central shelf (70 $\mathrm{m}$ to $130 \mathrm{~m}$ water depth).

\section{Macrophysiographic Features}

The cross-shelf high-resolution seismic records taken along the central and northern CODE lines exhibit two major changes in shelf bathymetry (Fig. 2). (1) At about $60 \mathrm{~m}$ water depth the more steeply inclined inner 
shelf zone (bottom gradient of about 0.02) grades to a relatively flat-lying central shelf section (bottom gradient of about 0.004). (2) The juncture between the flat-lying central shelf and the outer shelf along the northern CODE line has an abrupt bottom scarp of about 3 to 5 meters relief. This latter feature is caused by exposure of the more steeply dipping, resistant Tertiary basement rocks along the shelf break, probably caused by faulting. Other seismic records not shown here confirm the frequent surface exposure of the older basement rocks at the shelf break. (Klise, 1983).

During CODE-1 and CODE-2 (Table l) side-scan sonar profiles were taken along the tracklines shown in Fig. 4. The areal coverage is obviously concentrated in the vicinity of the major mooring sites along the central CODE line where bottom stress was estimated. The importance of sea-floor roughness in calculations of bottom stress has been indicated earlier and is more fully discussed in Grant et al (1983). One of the most important results to report is that near site C3, the sea floor is flat and featureless as determined from the side-scan sonar records (Fig. 5a). In the profiles taken near C3 during both CODE-1 and CODE-2 the sea floor is monotonously regular, devoid of relief discernible on our side-scan sonar records, except for drag marks that were found near the southeastern guard buoy at C3 during CODE-1 (Fig. 5b). These drag marks are several meters wide and about 100 meters long, oriented in a direction of about $300^{\circ} \mathrm{T}$. No data on the height of the drag marks is available, but our estimate based on the side-scan record is that sediment ridges caused by dragging may have been about 30 to $50 \mathrm{~cm}$ high. The tripod deployments during CODE-1 were more than 500 meters from the buoy locations and displaced either shoreward or seaward. We are confident that the bottom tripod measurements were not influenced by the presence of the localized drag marks near the guard-buoy anchors. 
In addition to the isolated instances of anchor drag marks near the guard buoys, we detected a regular pattern of bottom drag marks in water depths of 100 to 130 meters, probably caused by commercial fishing activities. These marks normally appear in the side-scan records as linear to gently curving, thin gouges of low relief having " $X$ " patterns (Fig. 6a). The spacing between adjacent, parallel marks is about 20 to 50 meters, with as many as 6 marks spaced nearly equidistant and parallel to one another across the sea floor. The most intense zone of occurrence of these features was in water depths of about 120 meters. Subdued, probably old drag marks due to fishing activities and a linear gouge caused by anchor dragging were found close to the C4 mooring (Fig. 6b). Otherwise, on the outer shelf in the immediate vicinity of sites $\mathrm{C} 4$ and $\mathrm{N} 4$ the sea floor is flat and featureless. However, as reported above, several kilometers from these sites in slightly greater depths ( 130 to 150 meters) rock outcrops are found along irregularly spaced patches. However, the only occurrences of these outer shelf "rough" areas in the sidescan records have low to nil relief in which the hard basement rock appears as dark patches (high sonic reflectivity) in an otherwise flat, non-distinctive bottom (Fig, 6C)

The side-scan profiles obtained in shallow water near Cl and C2 (Fig. 4) reveal a very rough bottom between the shallowest tracklines (about 35 meters depth) and about 60 meters depth. An example of this rocky, irregular bottom is shown in Fig. 7a, typical of the records taken in about 35 to 45 meters depth. The rock ledges and irregular outcrops probably are seaward extensions of the rocky promontories and bluffs that characterize the coast in this region. No rocky features were found within 0.5 kilometers of $\mathrm{Cl}$, but further to the north and south, many striking hard rock outcrops cover the seafloor. 
Other distinctive and common features of this inner shelf region were occurrences of cross-shelf channels irregularly spaced along the sea floor. At 42 meters depth seaward of Stewart's Point (Fig. 4) channels of low relief $(<1 \mathrm{~m})$ extend across the shelf approximately normal to the regional bathymetry (Cacchione, et al, 1983). The channels vary abruptly in width and orientation. In Fig. 7b one of these channels narrows to a thin, ribbon-like depression. The GEOPROBE location is about 90 meters from the nearest side of the low channel.

The interpretation of these features as channelized depressions is best derived from records like that shown in Figs. $7 \mathrm{~b}$ and $8 \mathrm{a}$. The strong and weak sonic reflections from the positive and negative relief, respectively, indicate the concave upward shape of the dark, linear zones. Also, visual observations taken by divers near the GEOPROBE and the surrounding sea floor (Fig. 7b) confirmed the channel-like nature of the features. The divers also reported that symmetric sand waves were located in the channels, and that smaller sand ripples were present on the sea floor near the GEOPROBE. Sediments in the channels were coarse-grained, shelly sands; the inter-channel areas were covered by fine sands.

All channels in our records contain large ripples usually arranged with crests transverse or slightly oblique to the channel sides (i.e., crests oriented approximately parallel to the general shelf bathymetry). The wavelengths of these ripples are between 1.0 to 1.7 meters, with the larger wavelengths generally found in shallower water. One portion of the side-scan record taken in 48 meters water depth south of Stewart's Point contains longcrested, linear to sinuous sand waves that extend for about $500 \mathrm{~m}$ in the alongshelf direction (Fig. 8b). The smaller sand ripples reported by the divers in the inter-channel areas are not resolvable in the side-scan records. 
Figure 9 was compiled from the available side-scan profiles taken in the CODE area (Fig. 4). The distribution of the coarse sediment channels containing symmetric ripples is very complex, although a preferred cross-shelf orientation is clearly evident. Available data suggest the channels occur amongst the rocky underwater zones in shallow water ( $<35 \mathrm{~m}$ depth) and extend to depths of about $60 \mathrm{~m}$.

The side-scan records taken on the central shelf in water depths of 70 to 120 meters are generally devoid of sea-floor relief, as reported earlier, except for occasional elongate, coast-parallel depressions that probably are sea-floor gouges caused by migratory grey whales (Fig. 8c). These features are usually linear gouges (infrequently "S" - shaped) about 2 to 8 meters long and 1 to 2 meters wide. They generally occur in groups of 3 to 8 arranged in a line oriented parallel to the bottom contours. The commonly measured spacing between multiple gouges is about 10 to 30 meters. In all of the records, the maximum density of whale gouges is about 10 to 20 gouges $/ 0.1 \mathrm{~km}^{2}$ and is located in water depths of 70 to 100 meters. No gouges were observed within 1 kilometer of the CODE mooring sites. During the Ll-81-NC Code-l cruise (Table 1), we observed numerous grey whales at the ocean surface migrating northward along the shelf. Poleward migrations of grey whales from mating areas off Mexico toward northern Pacific feeding grounds are common during February and March off California.

Small-scale. sea-f.loor. features

Sea-floor relief that is too small to be resolved by the side-scan sonar profiles and other high resolution seismic records is important to identify because of its potential influence on the bottom stress measurements. This smaller scale sea-floor "roughness" can be subdivided into three categories: 
(1) sedimentary textures (e.g. grain size);

(2) animal-induced structures (mounds, trails, burrows, etc.); and

(3) wave- and current-induced sedimentary bed forms ( $r$ ipples or small sand waves ).

The first two of these categories were investigated principally using box core samples. Locations of box core samples taken throughout the Pre-CODE and CODE program (Table 1) are shown in Figure 10. The high density of sample sites west of the Russian River and northwest of Horseshoe Point (Fig. 10) reflects the repeated deployments of GEOPROBE instrumentation in those areas. Mean grain sizes and sand/silt/clay content of surface samples taken from the box cores are listed in Table 3. Reference to Figure 10 indicates that the dominantly sandy surface inshore grades to dominantly silty sediments along the central shelf. Higher sand percentages are again found on the outer shelf, particularly in the southern part of the area (e.g., see stations 23 and 24 in Table 3 and Fig. 10). A generalized map of mean grain size distributions (Fig. 11) clearly depicts the nearshore, coarse surface materials grading to a silty central shelf of relatively high clay content (10-20\%). This central shelf mud deposit trends offshore towards Pt. Arena, and is bounded on its seaward margin by sandy surficial deposits probably of relict origin (Klise, 1983).

Down-core descriptions of selected box cores indicate the temporal persistence of this sedimentary pattern. The left column in each of the graphic displays in Fig. 12 shows the dominance of sandy materials throughout the box cores taken at shallow ( $\leq 50 \mathrm{~m}$ depth) and deep $(\geq 150 \mathrm{~m}$ depth) shelf locations. Note that samples 64 and 65 taken near the outer shelf $(130 \mathrm{~m}$ depth) are silty throughout; whereas samples 22 and 24 are completely sand or gravel throughout the entire core. 
The center and right columns in Fig. 12 indicate the extreme importance of biological activities in the bottom sediments of this region. Most of the box cores were totally bioturbated, with estimates of at least 90\% bioturbation in the cores. The types of biogenic structures seen visually or in the radiographs (depicted schematically in the right-hand column of Fig. 12) are dominantly burrows and trails.

Detailed descriptions of the organisms, including size and abundance, and their characteristic effects on the sediment surface are given in the Table in Appendix A. The four major types of organisms found in the samples were: (1) brittle stars; (2) heart urchins; (3) worms; and (4) molluscs. The brittle stars and urchins were particularly dense at central shelf sites. The urchins plow the sediment surface into ridges up to $4 \mathrm{~cm}$ high. Their bodies are typically between 1 to $4 \mathrm{~cm}$ in diameter (Appendix A). Time-series bottom photographs taken with the GEOPROBE camera system at sites $\mathrm{Cl}$, $\mathrm{C} 3$ and $\mathrm{C} 4$ confirm the surface disruptions caused by these organisms. The photographs shown in Fig. 13 are examples of the shelf surface at the GEOPROBE locations in CODE. At $\mathrm{C} 3$ the photographs (Fig. 13b) show that animal mounds and burrows dominate the small-scale relief. The mounds and burrows are randomly placed and vary greatly in number and location throughout the photographic record (about 2 months). The height of these animal-induced features is as great as 5 to $6 \mathrm{~cm}$ (Appendix A).

The third category of small-scale roughness, current-induced bed features, is most prominent in the sandy sediments of the innershelf $1 \leq 60 \mathrm{~m}$ depth). The GEOPROBE photographs at Cl (Fig. 13a) show a rippled bed with symmetrical oscillatory ripple marks having heights of about 3 to $5 \mathrm{~cm}$ and wavelengths of about 25 to $40 \mathrm{~cm}$. The ripple sizes and shapes changed in response to changes in the wave conditions over the eight days of photographs taken at $\mathrm{Cl}$. 
At C4 the bottom is relatively monotonous, and contrasts markedly to that at $\mathrm{C} 3$ by the paucity of biogenic surface structures (Fig. 13c). The bottom roughness scale here is about $l \mathrm{~cm}$. In general, there is a consistent decrease in the size of animal-induced structures offshore.

\section{DISCUSSION}

Two major geological factors control the large-scale bottom relief throughout the CODE area: (1) regional tectonic setting and (2) regional Holocene sedimentation pattern. The relatively narrow, rugged continental margin of central California is typical of a leading-edge plate boundary (Nordstrum and Inman, 1971). Active faulting and crustal movement along the San Andreas fault system which transects the CODE area (Fig. 1) have created an irregular coastline characterized by rocky headlands, promontories and stacks. Rock ledges dip steeply seaward in a general westerly direction and are exposed on the seafloor to $50 \mathrm{~m}$ water depth. The underwater ledges and outcrops create a very irregular, rough bathymetry along the inner shelf.

Secondly, sediment supplied by the Russian and Gualala Rivers during the Holocene has blanketed the central shelf, smoothing the irregularities probably caused by exposed older rock strata and by wave-cut features of the post-Wisconsin transgression. The Russian River supplies sediment mostly in the silt size class; little sand is presently being discharged by this river (Klise, 1983). Mid-water and near-bottom current data indicate a dominant poleward transport throughout the very late spring and summer months. PreCODE data (Cacchione and Drake, 1981) and wintertime current measurements at C3 (R. Beardsley, personal communication) also show dominant poleward transport. Sinking and rapid northward transport of the fine-grained sediments supplied by the Russian River would lead to a depositional pattern 
of fine sediments centered in the mid-shelf area and trending to the northwest, similar to the pattern found off the Columbia River (Smith and Hopkins, 1972), and precisely the pattern found in the CODE region (Fig. 11). Box cores and photographic evidence suggest that this modern silty lens of surficial materials is thoroughly bioturbated to depths of at least 50 cm. GEOPROBE data from pre-CODE and winter months also indicate that bottom stresses due to storm waves and currents mobilize the bottom materials and advect substantial quantities of this material northward (Drake and Cacchione, 1981).

Coarser surface sediments and steeper bottom gradients of the inner shelf are the result of resuspension by strong oscillatory bottom currents, particularly during wintertime storms, and advection of the fine sedimentary particles along or across the inner shelf by quasi-steady flows. The seaward extent of this wave-controlled surface ("shoreface") is about $60 \mathrm{~m}$ water depth in the CODE area, demarcated by the fining of the surface sediments (Fig. 11) and the abrupt decrease in bottom slope (Fig. 2).

Erosional channels containing relatively large symmetrical sand waves and relatively coarser sand than the inter-channel regions transect the shoreface in a general cross-shelf orientation. These channels are irregularly spaced along the coast, but appear to be associated with rocky promontories and ledges nearshore. Cacchione et. al. (1983) attribute the cross-shelf channels to the combined erosive action of strong downwelling-induced currents and large waves that are common during energetic wintertime storms. The finer sand at the shelf surface is resuspended by the high bottom stresses under the combined flows and is transported seaward by the bottom currents. The irregular spacing and widths of these channelized features suggests that the currents are locally intensified or steered by the numerous rock ledges along 
the inner shelf. The large symmetric ripples formed in the coarse sand within the channels are probably formed by oscillatory stresses generated during later winter periods by large incident swell from distant storms. During the CODE period, bottom currents along the inner shelf were generally too weak to form the channels or large ripples, and probably only contributed to reshaping the smaller oscillatory ripples on the interchannel surfaces.

The low to nil accumulation of fine-grained sediment on the outer shelf in the southern part of the CODE region and the higher silt and clay content at the outer shelf in the northern portion (Table 3, Fig. 10, Box cores 64 and 65) suggest poleward and offshore migration of the fine-grained sediment that is discharged from the Russian River. The relict sands and exposed outcrops which form the sea floor in the central to southern parts of the outer shelf probably indicate a combination of low supply and active transport of modern sediment. The current meter data from the moorings on the outer shelf during CODE 1 and CODE 2 will hopefully provide information on near-bottom currents and bottom stresses in these areas.

\section{SUMMARY}

\section{A. LARGE SCALE RELIEF}

1. Relatively narrow shelf $(\sim 20 \mathrm{~km})$ that diminishes in width from SE to NW •

2. Average cross-shelf gradient is 0.004 .

3. Irregularly spaced, submerged rock ledges and outcrops to about 50 meters depth.

4. Flat central shelf floored by silt.

5. Flat outer shelf floored by relict sand in southern part and sandy silt in northern part, except for occasional outcrops of underlying rock strata. 
B. SMALL SCALE RELIEF

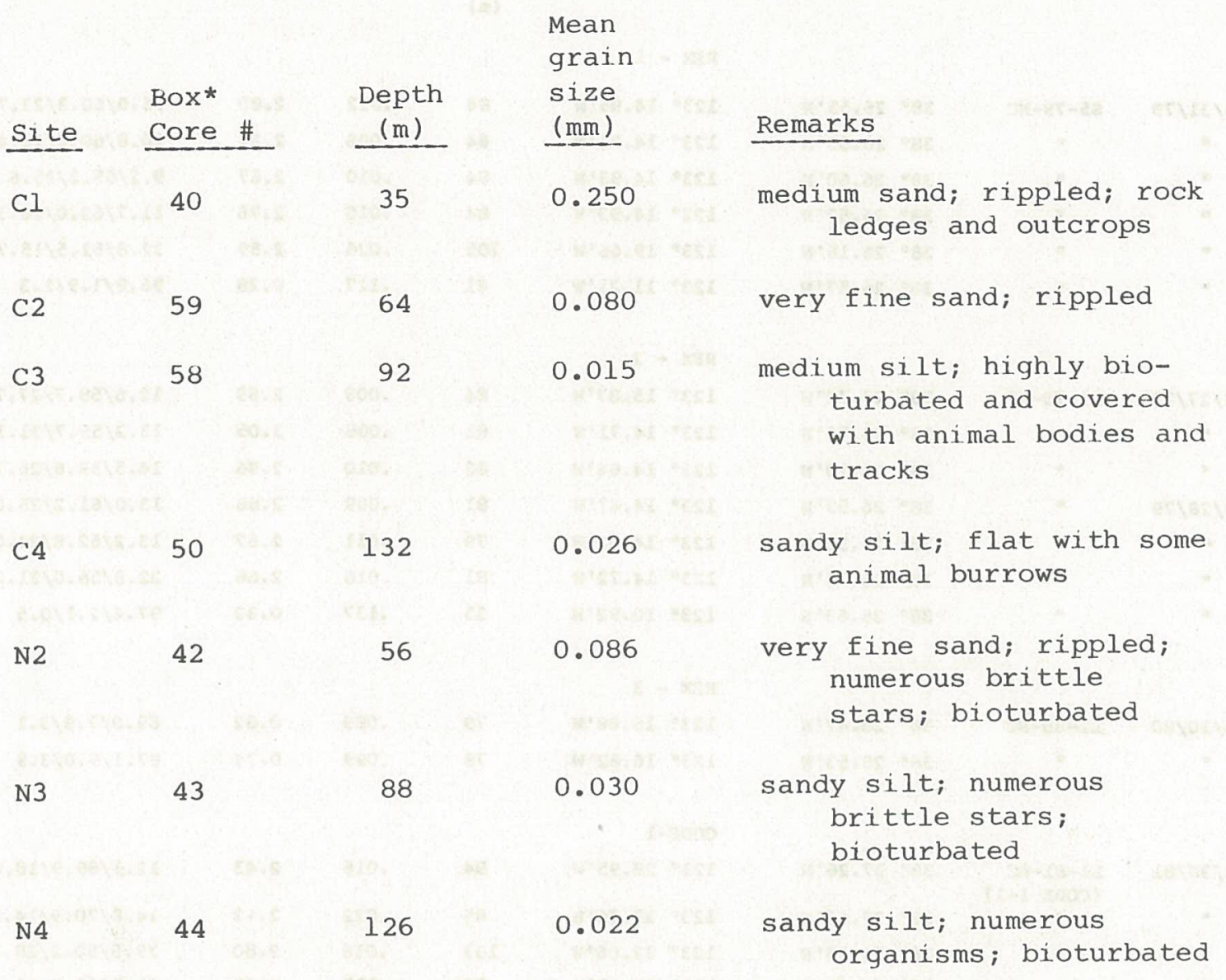

*Refer to Fig. 10 and Table 2 for locations. 
TABLE 3. Box Core locations and surface sample textural paraneters. sample numbers are consecutive and keyed to locations in Figure 10.

SAMPLE DATE CRUISE LATITUDE

LONGITUDE

WATER MEAN* SORTING
DEPTH SAND/SILT/CLAY
(mIn)
(ต)

REX - 1

$\begin{array}{llll}01 & 5 / 31 / 79 & 55-79-\mathrm{NC} & 38^{\circ} 26.55^{\prime} \mathrm{N} \\ 02 & * & * & 38^{\circ} 26.53^{\prime} \mathrm{N} \\ 03 & * & * & 38^{\circ} 26.60^{\prime} \mathrm{N} \\ 04 & * & * & 38^{\circ} 26.57^{\prime} \mathrm{N} \\ 05 & \cdots & * & 38^{\circ} 26.16^{\prime} \mathrm{N} \\ 06 & * & 38^{\circ} 26.57^{\prime} \mathrm{N}\end{array}$

$123^{\circ} 14.95^{\prime} \mathrm{W}$
$123^{\circ} 14.81^{\prime} \mathrm{W}$
$123^{\circ} 14.93^{\prime} \mathrm{W}$
$123^{\circ} 14.93^{\prime} \mathrm{W}$
$123^{\circ} 19.66^{\prime} \mathrm{W}$
$123^{\circ} 11.21^{\prime} \mathrm{W}$

$\begin{array}{rlll}84 & .012 & 2.80 & 16.0 / 60.3 / 23.7 \\ 84 & .008 & 2.84 & 10.8 / 60.8 / 28.4 \\ 84 & .010 & 2.67 & 9.2 / 65.2 / 25.6 \\ 84 & .010 & 2.76 & 11.7 / 62.0 / 26.3 \\ 105 & .026 & 2.59 & 32.8 / 51.5 / 15.7 \\ 41 & .117 & 0.28 & 96.8 / 1.9 / 1.3\end{array}$

\begin{tabular}{|c|c|c|c|}
\hline $10 / 27 / 79$ & LI-79-NC & $38^{\circ}$ & $27.34^{\prime} \mathrm{N}$ \\
\hline " & w & $38^{\circ}$ & $26.73^{\circ} \mathrm{N}$ \\
\hline & " & $38^{\circ}$ & $26.19^{\prime} \mathrm{N}$ \\
\hline $10 / 28 / 79$ & " & $38^{\circ}$ & $26.53^{\prime} \mathrm{N}$ \\
\hline - & " & $38^{\circ}$ & $26.50^{\prime} \mathrm{N}$ \\
\hline$\omega$ & " & $38^{\circ}$ & $26.78^{\prime} \mathrm{N}$ \\
\hline " & " & $38^{\circ}$ & $26.63^{\prime} \mathrm{N}$ \\
\hline
\end{tabular}

REX - 2

$123^{\circ} 15.87^{\prime} \mathrm{W}$
$123^{\circ} 14.71^{\prime} \mathrm{W}$
$123^{\circ} 14.64^{\prime} \mathrm{W}$
$123^{\circ} 14.47^{\prime} \mathrm{W}$
$123^{\circ} 14.62^{\prime} \mathrm{W}$
$123^{\circ} 14.72^{\prime} \mathrm{W}$
$123^{\circ} 10.92^{\prime} \mathrm{W}$

$\begin{array}{llll}84 & .009 & 2.89 & 12.6 / 59.7 / 27.7 \\ 81 & .008 & 3.05 & 13.2 / 55.7 / 31.1 \\ 82 & .010 & 2.86 & 14.5 / 58.8 / 26.7 \\ 81 & .009 & 2.66 & 13.0 / 61.2 / 25.8 \\ 79 & .011 & 2.67 & 13.2 / 62.8 / 24.0 \\ 81 & .016 & 2.66 & 22.8 / 56.0 / 21.2 \\ 35 & .137 & 0.32 & 97.4 / 2.1 / 0.5\end{array}$

\begin{tabular}{|c|c|c|}
\hline $4 / 10 / 80$ & $L 1-80-N C$ & $38^{\circ}$ \\
\hline$\omega$ & " & $38^{\circ}$ \\
\hline
\end{tabular}

REX - 3

$123^{\circ} 16.88^{\prime} \mathrm{W}$

7

7

$123^{\circ} 16.82^{\circ} \mathrm{W}$

.089

0.62

$89.0 / 7.9 / 3.1$

0.74

$87.1 / 9.0 / 3.9$

CODE-1

\begin{tabular}{|c|c|c|c|c|}
\hline 16 & $3 / 30 / 81$ & $\begin{array}{l}11-81-N C \\
(C O D E 1-1)\end{array}$ & $38^{\circ}$ & $37.26^{\prime} \mathrm{N}$ \\
\hline 17 & " & $n$ & $38^{\circ}$ & $37.63^{\prime} \mathrm{N}$ \\
\hline 18 & $\omega$ & " & $38^{\circ}$ & $34.36^{\prime} \mathrm{N}$ \\
\hline 19 & ". & " & $38^{\circ}$ & $38.28^{\prime} \mathrm{N}$ \\
\hline 20 & $\omega$ & " & $38^{\circ}$ & $38.77^{\prime} \mathrm{N}$ \\
\hline 21 & " & $"$ & $38^{\circ}$ & $38.6^{\prime} \mathrm{N}$ \\
\hline 22 & $\infty$ & $n$ & $38^{\circ}$ & $19.06^{\prime} \mathrm{N}$ \\
\hline 23 & " & " & $38^{\circ}$ & $22.6^{\prime} \mathrm{N}$ \\
\hline 24 & " & " & $38^{\circ}$ & $21.08^{\prime} \mathrm{N}$ \\
\hline 25 & ๓. & " & $38^{\circ}$ & $21.96^{\prime} \mathrm{N}$ \\
\hline 26 & $3 / 31 / 81$ & " & $38^{\circ}$ & $27.12^{\prime} \mathrm{N}$ \\
\hline 27 & " & " & $38^{\circ}$ & $28.38^{\prime} \mathrm{N}$ \\
\hline 28 & $\cdots$ & $"$ & $38^{\circ}$ & $25.82^{\prime} \mathrm{N}$ \\
\hline 29 & " & " & $38^{\circ}$ & $24.96^{\prime} \mathrm{N}$ \\
\hline 30 & $4 / 1 / 81$ & $\begin{array}{l}11-81-N C \\
(C O D E 1-1)\end{array}$ & $38^{\circ}$ & $39.80^{\prime} \mathrm{N}$ \\
\hline 31 & " & $\infty$ & $38^{\circ}$ & $40.06^{\prime} \mathrm{N}$ \\
\hline 32 & $4 / 2 / 81$ & $n$ & $38^{\circ}$ & $31.67^{\prime} \mathrm{N}$ \\
\hline 33 & $4 / 2 / 81$ & " & $38^{\circ}$ & $29.43^{\prime} \mathrm{N}$ \\
\hline 34 & " & $\varpi$ & $38^{\circ}$ & $27.03^{\circ} \mathrm{N}$ \\
\hline 35 & " & " & $38^{\circ}$ & $25.22^{\prime} \mathrm{N}$ \\
\hline 36 & $6 / 13 / 81$ & $\begin{array}{l}\text { WE6-81-NC } \\
(C O D E 1-2)\end{array}$ & $38^{\circ}$ & $38.19^{\prime} \mathrm{N}$ \\
\hline 37 & " & $n$ & $38^{\circ}$ & $38.04^{\prime} \mathrm{N}$ \\
\hline 38 & " & w & $38^{\circ}$ & $37.91 ' N$ \\
\hline 39 & ต & 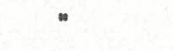 & $38^{\circ}$ & $39.30^{\prime} \mathrm{N}$ \\
\hline 40 & ๓ & & $38^{\circ}$ & $39.51^{\prime} \mathrm{N}$ \\
\hline 41 & • & & $38^{\circ}$ & $39.5^{\prime} \mathrm{N}$ \\
\hline
\end{tabular}

\begin{tabular}{|c|c|c|c|c|c|c|}
\hline $123^{\circ}$ & $28.95^{\prime} w$ & 94 & .016 & 2.43 & $12.1 / 69.9 / 18.0$ & \\
\hline $123^{\circ}$ & $27.46^{\prime} w$ & 85 & .022 & 2.12 & $14.8 / 70.9 / 14.3$ & \\
\hline $123^{\circ}$ & $32.06^{\prime} w$ & 133 & .018 & 2.80 & $29.5 / 50.2 / 20.3$ & \\
\hline $123^{\circ}$ & $26.48^{\prime} w$ & 76 & .028 & 2.23 & $21.7 / 65.3 / 13.0$ & \\
\hline $123^{\circ}$ & $25.85^{\prime} \mathrm{w}$ & 53 & .020 & 2.53 & $22.0 / 60.5 / 17.5$ & \\
\hline $123^{\circ}$ & $26.1^{\prime} \mathrm{w}$ & 68 & .516 & 0.86 & $86.5 / 0.6 / 0.4$ & 由* \\
\hline $123^{\circ}$ & $28.43^{\prime} w$ & 220 & .087 & 0.93 & $85.3 / 9.8 / 4.9$ & \\
\hline $123^{\circ}$ & $24.7^{\prime} w$ & 145 & .111 & 1.08 & $85.8 / 9.5 / 4.7$ & \\
\hline $123^{\circ}$ & $24.97^{\circ} \mathrm{w}$ & 142 & .112 & 1.17 & $87.0 / 8.0 / 5.0$ & \\
\hline $123^{\circ}$ & $21.38^{\prime} \mathrm{W}$ & 116 & .093 & 1.29 & $78.4 / 16.9 / 4.7$ & \\
\hline $123^{\circ}$ & $10.00^{\prime} \mathrm{w}$ & 26 & .156 & 0.55 & $93.8 / 4.8 / 1.4$ & \\
\hline $123^{\circ}$ & $10.76^{\prime} \mathrm{w}$ & 21 & .536 & 0.43 & $99 \cdot 2 / 0.5 / 0.3$ & \\
\hline $123^{\circ}$ & $13.35^{\prime} w$ & 73 & .009 & 2.57 & $7.7 / 67.4 / 24.9$ & \\
\hline $123^{\circ}$ & $15.10^{\prime} \mathrm{W}$ & 88 & .011 & 2.97 & $17.4 / 58 \cdot 3 / 20.3$ & \\
\hline $123^{\circ}$ & $25.75^{\prime} \mathrm{W}$ & 40 & .270 & 0.33 & $98.9 / 0.7 / 0.4$ & \\
\hline $123^{\circ}$ & $26.36^{\prime} w$ & 52 & .227 & 0.69 & $94.7 / 2.9 / 2.4$ & \\
\hline $123^{\circ}$ & $23.75^{\prime} \mathrm{w}$ & 99 & .019 & 2.68 & $22.7 / 59.0 / 18.3$ & \\
\hline $123^{\circ}$ & $26.03^{\prime} \mathrm{w}$ & 123 & .022 & 2.84 & $36.0 / 45.9 / 18.1$ & \\
\hline $123^{\circ}$ & $23.68^{\prime} w$ & 120 & .030 & 2.65 & $45.3 / 39.1 / 5.6$ & \\
\hline $123^{\circ}$ & $27.26^{\prime} \mathrm{w}$ & 138 & .144 & 1.08 & $\begin{array}{c}88.5 / 7.5 / 4.0 \\
\text { !. } 1\end{array}$ & \\
\hline $123^{\circ}$ & $24.82^{\prime} w$ & 52 & .362 & 0.58 & $93.2 / 2.5 / 1.2$ & $\Rightarrow$ \# \\
\hline $123^{\circ}$ & $24.65^{\prime} \mathrm{w}$ & 52 & .632 & 1.66 & $81.9 / 2.8 / 1.2$ & \# \\
\hline $123^{\circ}$ & $24.51^{\prime} w$ & 53 & .205 & 1.90 & $86.8 / 9.2 / 4.0$ & \\
\hline $123^{\circ}$ & $25.42^{\prime} w$ & 45 & .259 & 0.33 & $96.3 / 2.5 / 1.2$ & \\
\hline $123^{\circ}$ & $25.35^{\prime} w$ & 35 & .246 & 0.32 & $94.9 / 1.9 / 0.8$ & 해 \\
\hline $123^{\circ}$ & $25.2^{\circ} \mathrm{W}$ & 34 & .249 & 0.33 & $97.0 / 2.0 / 1.0$ & \\
\hline
\end{tabular}




\begin{tabular}{|c|c|c|c|c|c|c|c|c|c|c|}
\hline 42 & $3 / 6 / 82$ & $\begin{array}{l}\text { WE2-82-NC } \\
(\text { CODE 2-1) }\end{array}$ & $38^{\circ}$ & $49.6^{\prime} \mathrm{N}$ & $123^{\circ}$ & $39.6^{\prime} \mathrm{W}$ & 56 & .086 & 3.01 & $54.9 / 30.1 / 8.7 \quad$. \\
\hline 43 & " & " & $38^{\circ}$ & $48.5^{\prime} \mathrm{N}$ & $123^{\circ}$ & $41.3^{\prime} \mathrm{W}$ & 88 & .030 & 2.29 & $29.3 / 57.1 / 13.6$ \\
\hline 44 & $n$ & " & $38^{\circ}$ & $45.8^{\prime} \mathrm{N}$ & $123^{\circ}$ & $43.9^{\prime} \mathrm{W}$ & 126 & .022 & 2.68 & $31.6 / 50.9 / 17.5$ \\
\hline 45 & $3 / 7 / 82$ & $"$ & $38^{\circ}$ & $34.0^{\prime} \mathrm{N}$ & $123^{\circ}$ & $33.3^{\prime} \mathrm{w}$ & 130 & .019 & 2.90 & $29.2 / 51.4 / 19.4$ \\
\hline 46 & $"$ & $"$ & $38^{\circ}$ & $36.4^{\prime} \mathrm{N}$ & $123^{\circ}$ & $27.7 . \mathrm{W}$ & 90 & .019 & 2.17 & $10.9 / 73.4 / 15.7$ \\
\hline 47 & $5 / 1 / 82$ & $\begin{array}{l}\text { WE7-82-NC } \\
(\text { CODE 2-2) }\end{array}$ & $38^{\circ}$ & $36.67 \cdot N$ & $123^{\circ}$ & $27.04^{\prime} W$ & 89 & .016 & 2.20 & $7.7 / 75.4 / 16.9$ \\
\hline 48 & $5 / 4 / 82$ & " & $38^{\circ}$ & $33.41 \cdot \mathrm{N}$ & $123^{\circ}$ & $31.42^{\prime} \mathrm{W}$ & 132 & .023 & 2.71 & $36.2 / 46.9 / 16.9$ \\
\hline 49 & " & $"$ & $38^{\circ}$ & $33.34^{\prime} \mathrm{N}$ & $123^{\circ}$ & $31.43^{\prime} \mathrm{W}$ & 132 & .026 & 2.60 & $35.6 / 48.6 / 15.2$ \\
\hline 50 & $"$ & $n$ & $38^{\circ}$ & $33.41^{\prime} \mathrm{N}$ & $123^{\circ}$ & $31.43^{\prime} \mathrm{w}$ & 132 & .027 & 2.56 & $38.3 / 46.3 / 15.4$ \\
\hline 51 & $"$ & " & $38^{\circ}$ & $33.34 \mathrm{~N}$ & $123^{\circ}$ & $31.40^{\prime} \mathrm{W}$ & 132 & .033 & 2.55 & $45.9 / 40.0 / 14.1$ \\
\hline 52 & $5 / 5 / 82$ & " & $38^{\circ}$ & $48.61^{\prime} \mathrm{N}$ & $123^{\circ}$ & $41.66^{\prime} \mathrm{W}$ & 94 & .031 & 2.01 & $24.3 / 64.4 / 11.3$ \\
\hline 53 & $"$ & $n$ & $38^{\circ}$ & $48.65^{\prime} \mathrm{N}$ & $123^{\circ}$ & $41.60^{\prime} \mathrm{w}$ & 94 & .035 & 1.95 & $24.2 / 64.0 / 10.1$ \\
\hline 54 & " & $"$ & $38^{\circ}$ & $50.08^{\prime} \mathrm{N}$ & $123^{\circ}$ & $40.32^{\prime} \mathrm{w}$ & 64 & .068 & 1.59 & $63.1 / 30.9 / 6.0$ \\
\hline 55 & $"$ & " & $38^{\circ}$ & $38.58^{\prime} \mathrm{N}$ & $123^{\circ}$ & $25.40^{\circ} \mathrm{w}$ & 63 & .121 & 2.01 & $78.4 / 15.5 / 6.1$ \\
\hline 56 & $"$ & " & $38^{\circ}$ & $38.89^{\prime} \mathrm{N}$ & $123^{\circ}$ & $25.70^{\prime} \mathrm{w}$ & 63 & .036 & 2.75 & $45.9 / 39.8 / 14.3$ \\
\hline 57 & $7 / 30 / 82$ & $\begin{array}{l}\text { WE1O-82-NC } \\
(\text { CODE 2-3) }\end{array}$ & $38^{\circ}$ & $36.68^{\prime} \mathrm{N}$ & $123^{\circ}$ & $27.34^{\prime} \mathrm{W}$ & 89 & .006 & 2.75 & $5.0 / 61.3 / 33.7$ \\
\hline 58 & $"$ & $"$ & $38^{\circ}$ & $36.16^{\prime} \mathrm{N}$ & $123^{\circ}$ & $27.50^{\prime} w$ & 92 & .015 & 2.25 & $10.0 / 72.0 / 18.0$ \\
\hline 59 & " & n & $38^{\circ}$ & $38.05^{\prime} \mathrm{N}$ & $123^{\circ}$ & $25.32^{\prime} \mathrm{W}$ & 64 & .396 & 1.52 & $86.2 / 8.1 / 5.3$ ** \\
\hline 60 & " & $"$ & $38^{\circ}$ & $43.77 \cdot \mathrm{N}$ & $123^{\circ}$ & $32.80^{\prime} \mathrm{W}$ & 63 & .077 & 2.67 & $64.5 / 24.8 / 10.7$ \\
\hline 61 & $"$ & " & $38^{\circ}$ & $42.68 \cdot \mathrm{N}$ & $123^{\circ}$ & $34.02^{\prime} \mathrm{W}$ & 89 & .022 & 2.77 & $24.0 / 59.1 / 16.9$ \\
\hline 62 & $7 / 31 / 82$ & $n$ & $38^{\circ}$ & $49.20^{\prime} \mathrm{N}$ & $123^{\circ}$ & $39.93^{\prime} \mathrm{W}$ & 65 & .042 & 2.19 & $50.3 / 38.5 / 11.2$ \\
\hline 63 & $"$ & $"$ & $38^{\circ}$ & $48.27^{\prime} \mathrm{N}$ & $123^{\circ}$ & $42.03^{\prime} \mathrm{W}$ & 93 & .028 & 2.16 & $24.6 / 62.5 / 12.8$ \\
\hline 64 & " & " & $38^{\circ}$ & $45^{\prime} .9 \mathrm{~N}$ & $123^{\circ}$ & $45.5^{\prime} \mathrm{W}$ & 131 & .031 & 2.52 & $43.4 / 42.3 / 14.3$ \\
\hline 65 & " & $n$ & $38^{\circ}$ & $39.6^{\circ} \mathrm{w}$ & $123^{\circ}$ & $38.4^{\prime} \mathrm{W}$ & 132 & .030 & 2.63 & $41.5 / 43.3 / 15.2$ \\
\hline
\end{tabular}

- Mean and sorting derived according to Folk and ward (1957)

-* Balance consists of gravel and/or mollusk shells 



\section{REFERENCES}

Allen, J.S., Beardsley, R.C., Brown, W.S., Cacchione, D.A., Davis, R.E., Drake, D.E., Friehe, C., Grant, W.D., Huyer, A., Irish, J.D., Janopaul, M.M., Williams, A.J., and Winant, C.D., 1982, A preliminary description of the CODE-I field program, Woods Hole Oceanographic Institution Tech. Report 82-51.

Cacchione, D.A. and Drake, D.E., 1981, Near-bottom current measurements off the Russian River, California (Abs.), Trans. Amer. Geophys. Union, 62(45), P. 912

Cacchione, D.A., and Drake, D.E., 1982, Measurements of storm generated bottom stresses on the continental shelf. J. Geophys. Res., 87 No. C3, 1952-1961, 1982

Cacchione, D.A., Drake, D.E., Grant, W.D., and Tate, G., 1983, Rippled scour depressions on the inner continental shelf off central California, Jour. Sed. Petrology, in press.

Drake, D.E. and D.A. Cacchione, 1981, Near-bottom currents and sediment transport on the continental shelf off the Russian River, California (abs.), Trans. Amer. Geophys. Union, 62(45), p. 916.

Glenn, S.M., 1983, A continental shelf bottom boundary layer model: The effects of waves, currents and a moveable bed. WHOI/MIT Joint Program Sc. D. Thesis, February 1983, 237 p. 
Grant, W.D., 1982, The influence of internal waves on near bottom velocity profiles measured on the continental shelf: stress and roughness estimates, Trans. Am. Geophys. v. 63 No. 45, 987.

Grant, W.D., Boyer, L. and Sanford, L.P., 1982, The effect of bioturbation on the iniation of motion of intertidal sands, J. of Marine Res.. 40 (3), $659-677$

Grant, W.D. and Glenn, S.M., Continental shelf bottom boundary layer model, Volume I: Theoretical Model, Final report to the American Gas Association, 160 p. (in press).

Grant, W.D. and Madsen, O.S., 1979, Combined wave and current interaction with a rough bottom, J.. of. Geophys..Res., 84 (C4), 1797-1808.

Grant, W.D. and Madsen, O.S., 1982, Moveable bed roughness in unsteady oscillatory flow, J...of. Geophys..Res.,..87 (Cl) 469-481.

Grant, W.D., Williams, A.J. III, Glenn, S.M., Cacchione, D.A. and Drake, D.E., 1983, High frequency bottom stress variability and its prediction in the CODE region, Woods Hole Oceanographic Institution Tech. Report 83-19, $72 \mathrm{p}$.

Inman, D.L. and Nordstrum, C.E., 1971, On the tectonic and morphologic classification of Coasts, J. Geol., 7.9, p. 1-21. 
Klise, D.E., 1983, Modern sedimentation on the California continental margin adjacent to the Russian River: Thesis, Master of Science, Department of Geology, San Jose State University, $143 \mathrm{p}$.

McCulloch, D., 1980, A summary report of the regional geology, environmental geology, oCS resource appraisal, petroleum potential and operational considerations in the area of proposed Lease Sale 73, offshore California, U.S. Geol. Survey Open File Rept. 80-2007, 150 p.

Nowell, A.R.M., Jumars, P.A. and Self, R.F.L., 1981, A Markov model of flow sediment-organism interactions: fluid mechanical and biological processes affecting the transitions probabilities, in Proceedings. International Geol. Cong. Cont., Nittrouier, Paris France.

Rhoads, D.C., J.Y. Yingst and Ullman, W., 1978, Seafloor stability in central Long Island Sound: Pt. 1: Temporal changes in erodibility of fine grained sediment, in Estuarine Interactions, Wiley, M.L., ed., Academic Press, 221-244.

Smith, J.D., 1977, Modeling of sediment transport on continental shelves, in The. Sea, .Vol...6., Wiley - Interscience, N.Y.

Smith, J.D. and Mclean, S.R., 1977, Spatically averaged flow over a wavy surface, J..Geophy.s..Res., 82 (12), 1735-1746. 
Smith, J.D. and Hopkins, T.S., 1972, Sediment transport on the continental shelf off the Washington and Oregon in light of recent current measurements: in Swift, D.J.P., Duane, D.B., Pilkey, O.H. (eds.), Shelf Sediment Transport: Process and Pattern, Dowden, Hutchinson and Ross, Stroudsburg, PA, pp. 83-97. 
The results and interpretations found in this report represent a collective effort by a number of investigators who, although not 1 isted as authors, have contributed greatly to the data collection, sedimentological and geophysical analyses. In particular we have obtained sediment data and useful insights from Mr. David Klise, who has recently completed a Master's thesis at San Jose State University on the sedimentary history of the continental shelf region from the Russian River to Point Arena. We hope that we have not misrepresented his viewpoints and that we have properly acknowledged his contributions in the text. Dr. Fred Nichols and Ms. Jan McHendrie collected the biological specimens and compiled the description of organisms found in the box cores and in the GEOPROBE photographs. Their results are given principally in Appendix A. Dr. Gary Hill used the box core slabs for x-ray radiographic analysis and contributed Figure 12. Dr. David McCulloch, who has been conducting geological and geophysical research on the central California continental margin for a number of years, provided valuable background information. We have relied on Mr. Theodore Clarke and Ms. Joanne Thede to provide the bulk of the laboratory work and figure compilations; without their diligent efforts, this report could not have been completed. We also are indebted to Dr. Herman Karl and Dr. David Rubin for their careful reviews of the manuscript. We thank each of these and the crews of the $R / V$ Wecoma and R/V Samuel P. Lee. This work was partially sponsored by the National Science Foundation on Grant No. OCE80-14938 and by the United States Geological Survey. Printing of the report was on NSF Grant No. OCE80-14941. We thank R. Beardsley for this support. This is CODE Technical Report No. 16. 



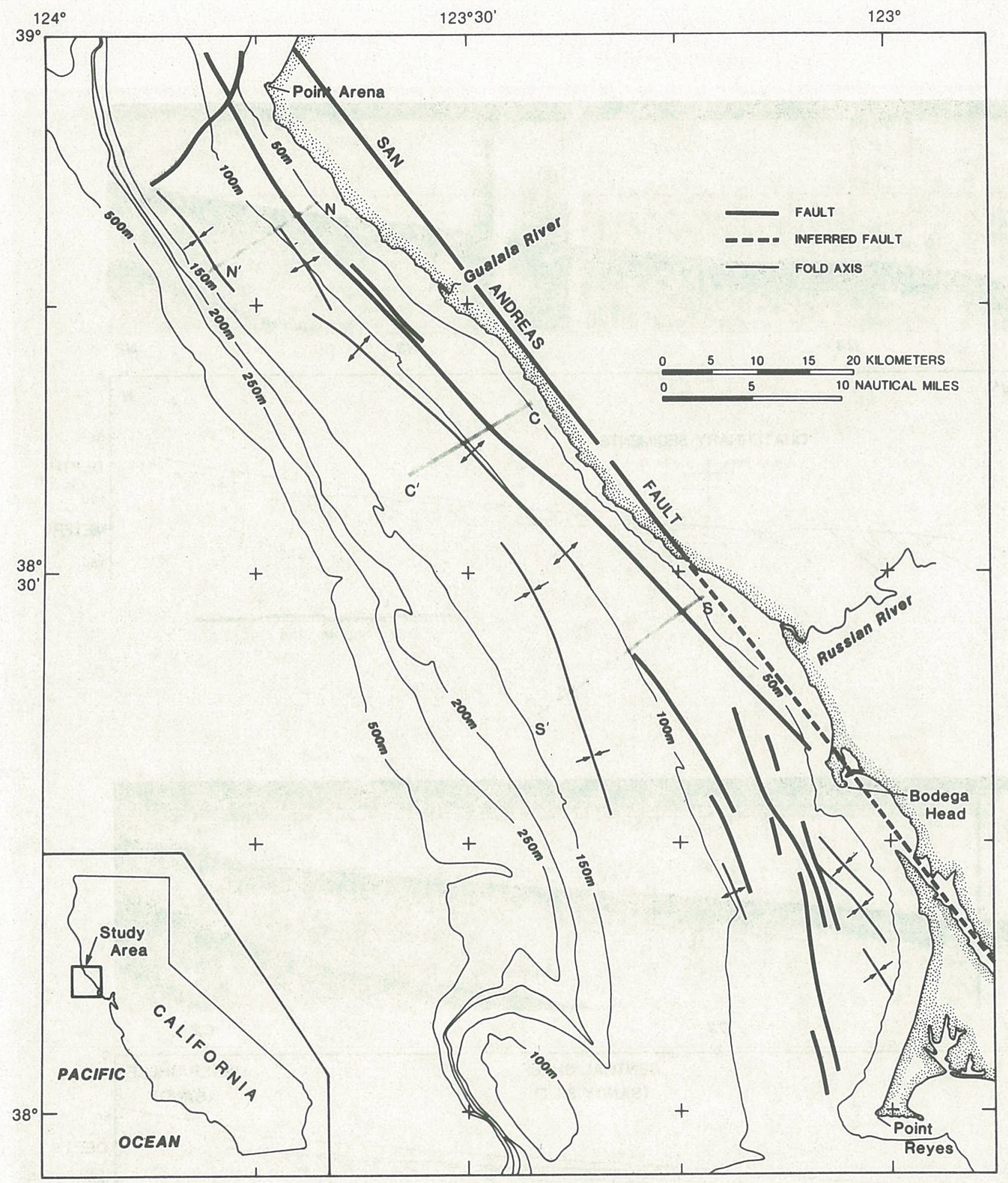

Fig. 1. Location map showing coastline, rivers, bathymetry and major structural features in CODE region. Lines $N_{-} \mathrm{N}^{\prime}, \mathrm{C}-\mathrm{C}^{\prime}$ and $\mathrm{S}^{-S^{\prime}}$ indicate major transects along which moored instrumentation was emplaced during CODE-1. 


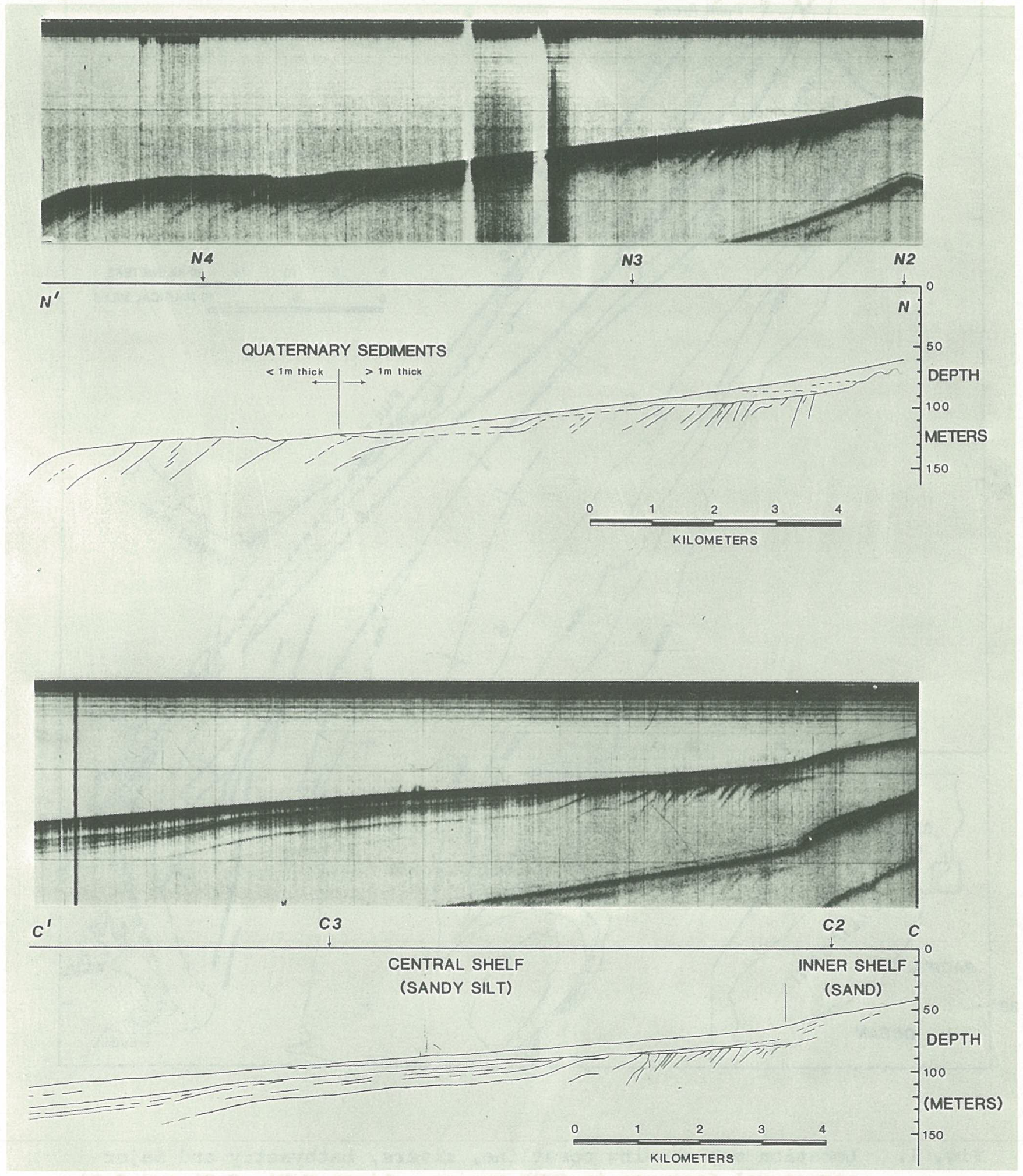

Fig. 2. $\quad 3.5 \mathrm{kHz}$ seismic profiles along North ( $\left.N-\mathrm{N}^{\prime}\right)$ and central (C-C') CODE lines. Interpreted sections are below actual records. 

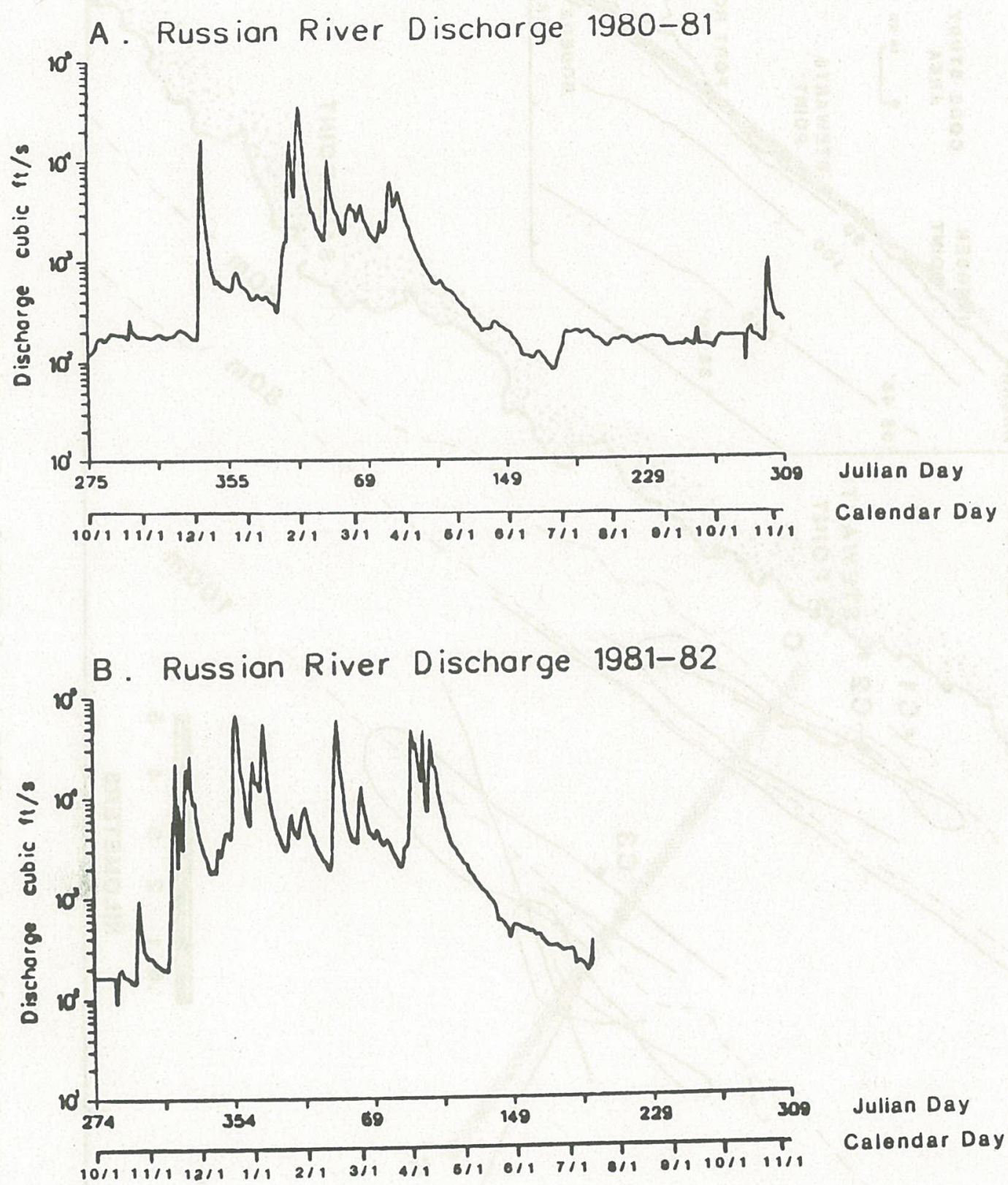

Fig. 3. Russian River discharge curves for 1981 (A) and 1982 (B). 


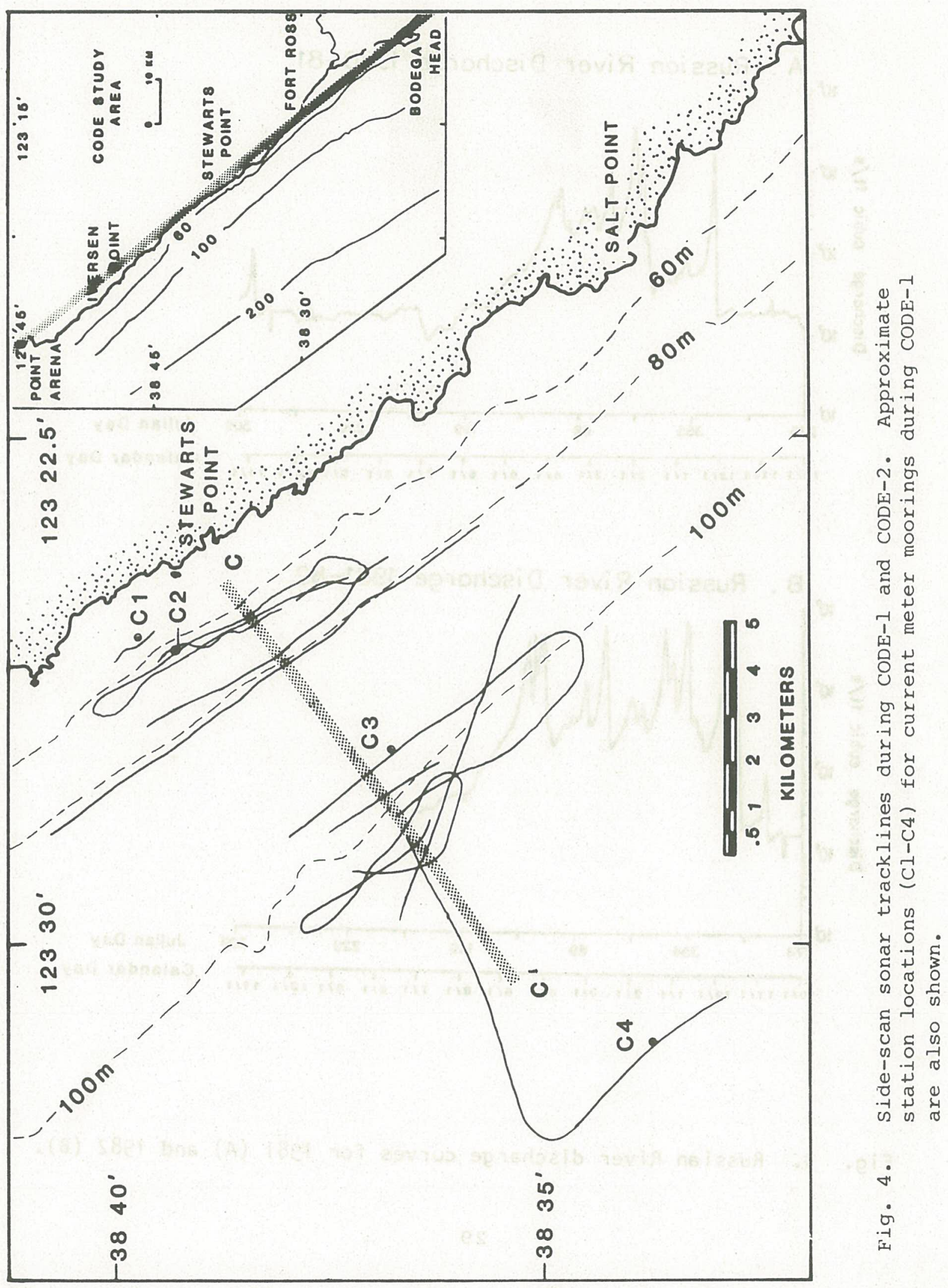



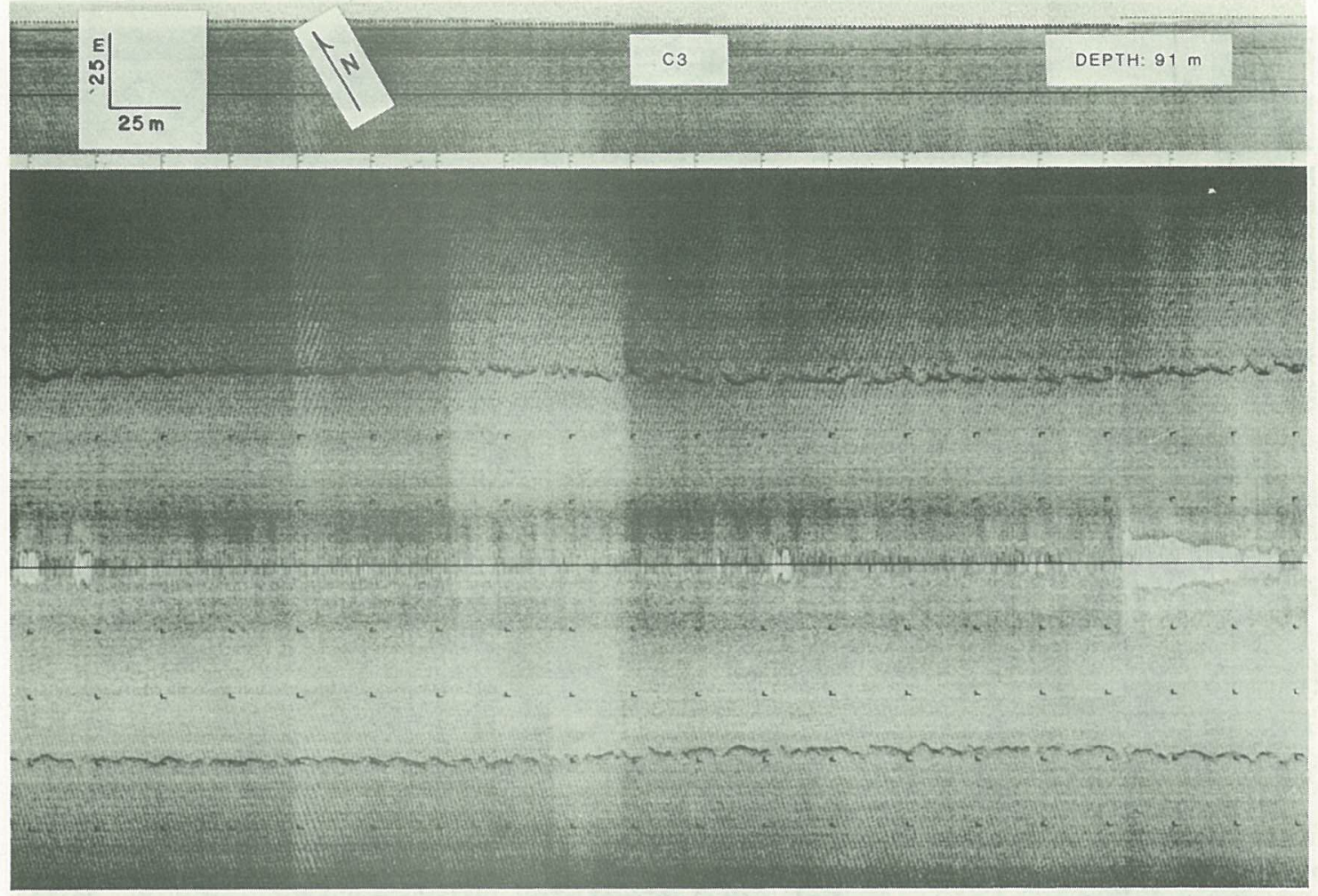

Fig. 5a. Side-scan sonar record taken near C3. Wavy line on either lobe parallel to track is caused by secondary reflection from sea surface.

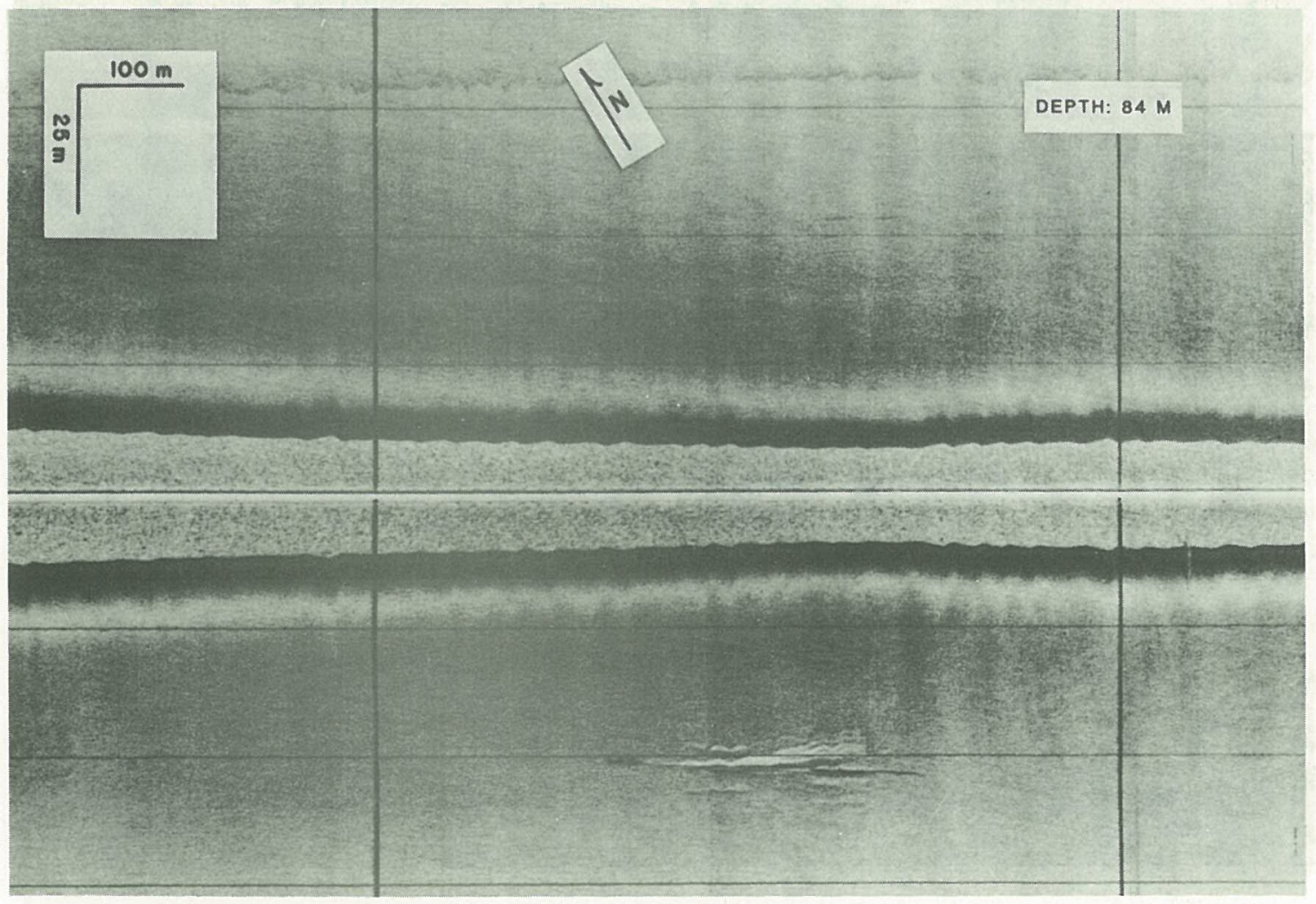

Fig. 5b. Side-scan sonar record near c3 showing bottom drag marks caused by anchors during deployment of SE guard buoy. Otherwise bottom is flat and featureless. 


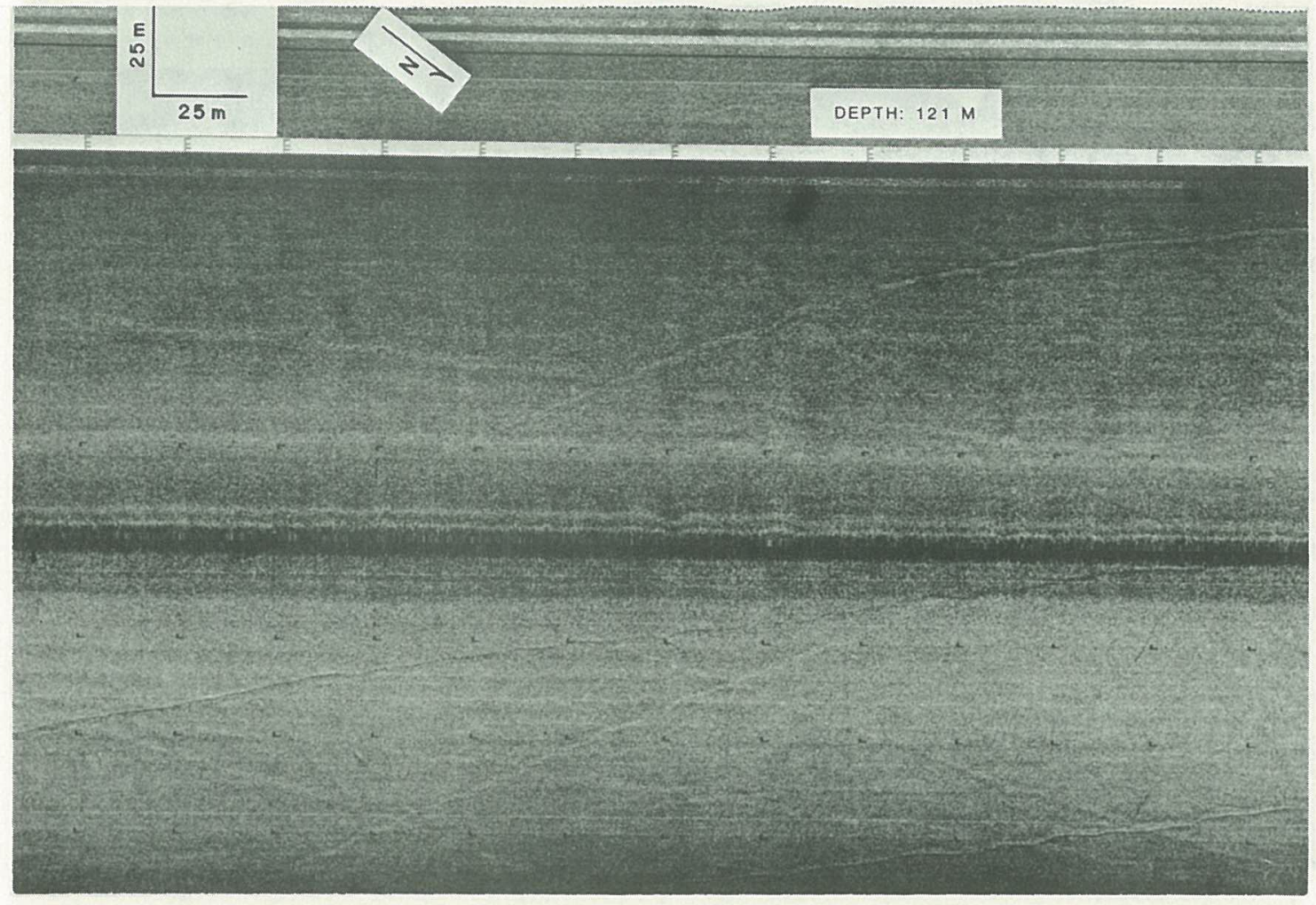

Fig. 6a. Side-scan sonar record of relatively "fresh" bottom drag marks on central shelf caused by fishing activities.

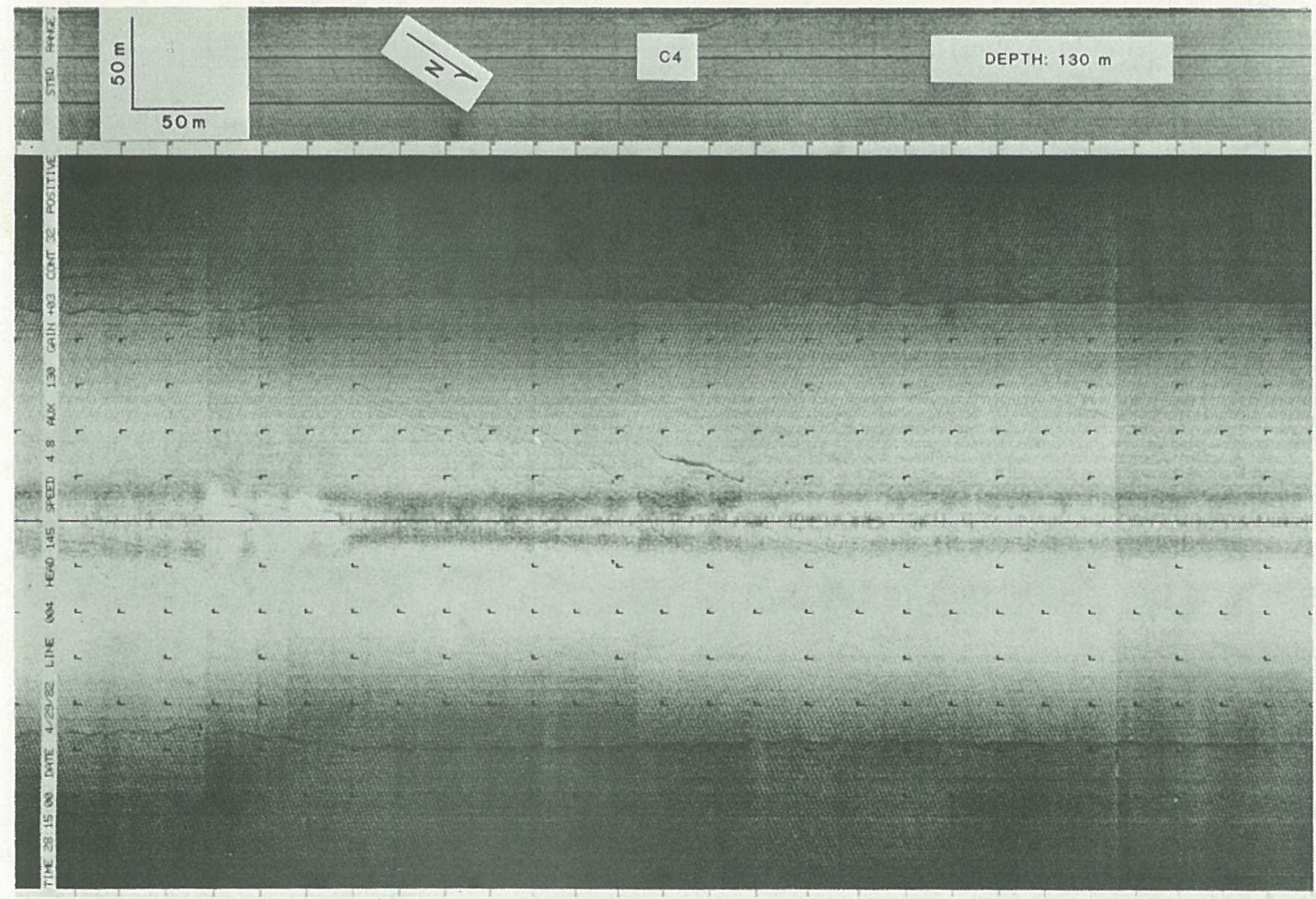

Fig. 6b. Bottom drag marks with approximate north-south orientations near C4. Dark wavy reflector near center of record is possibly caused by anchor drag marks from C4 mooring. 


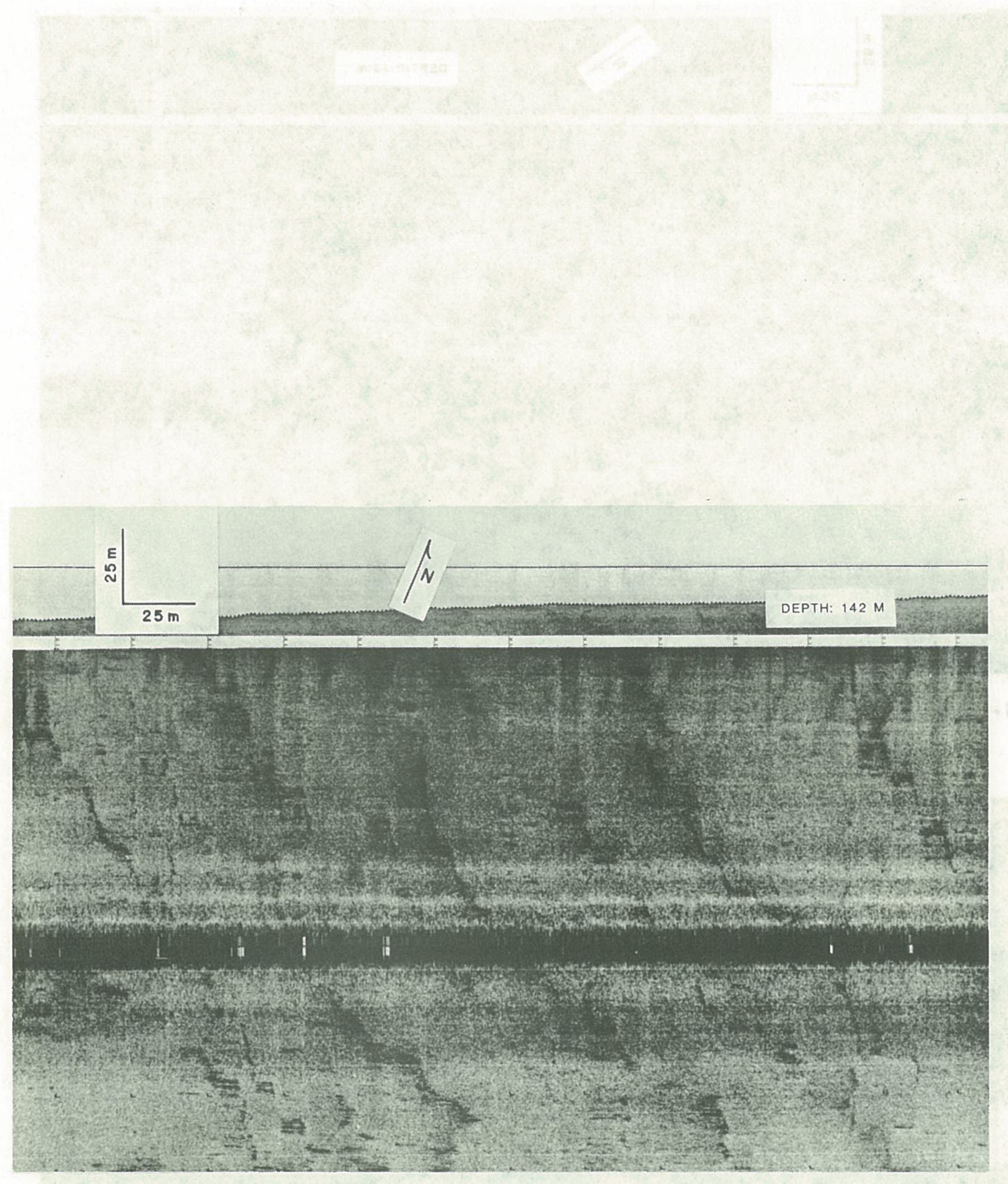

Fig. 6c. Side-scan sonar record of patchy, low outcrops exposed or thinly veneered by sand on outer shelf. Outcrop lineations are in northwesterly orientation, approximately parallel to shelf break. 


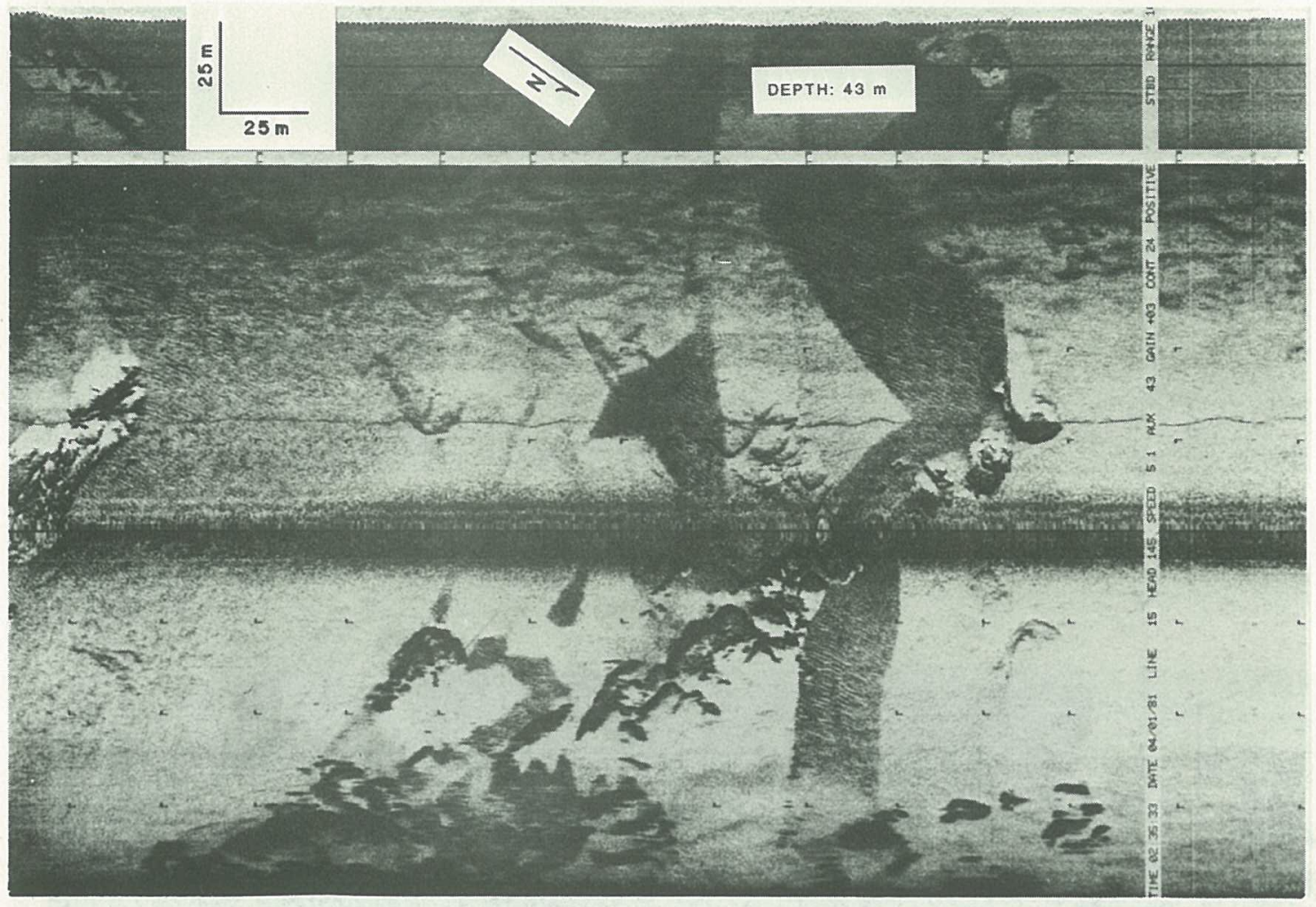

Fig. 7a. Digital side-scan sonar record showing rock outcrops and ledges amongst sandy bedforms. Erosional channel containing large symmetrical sand waves can be clearly seen trending cross-shelf.

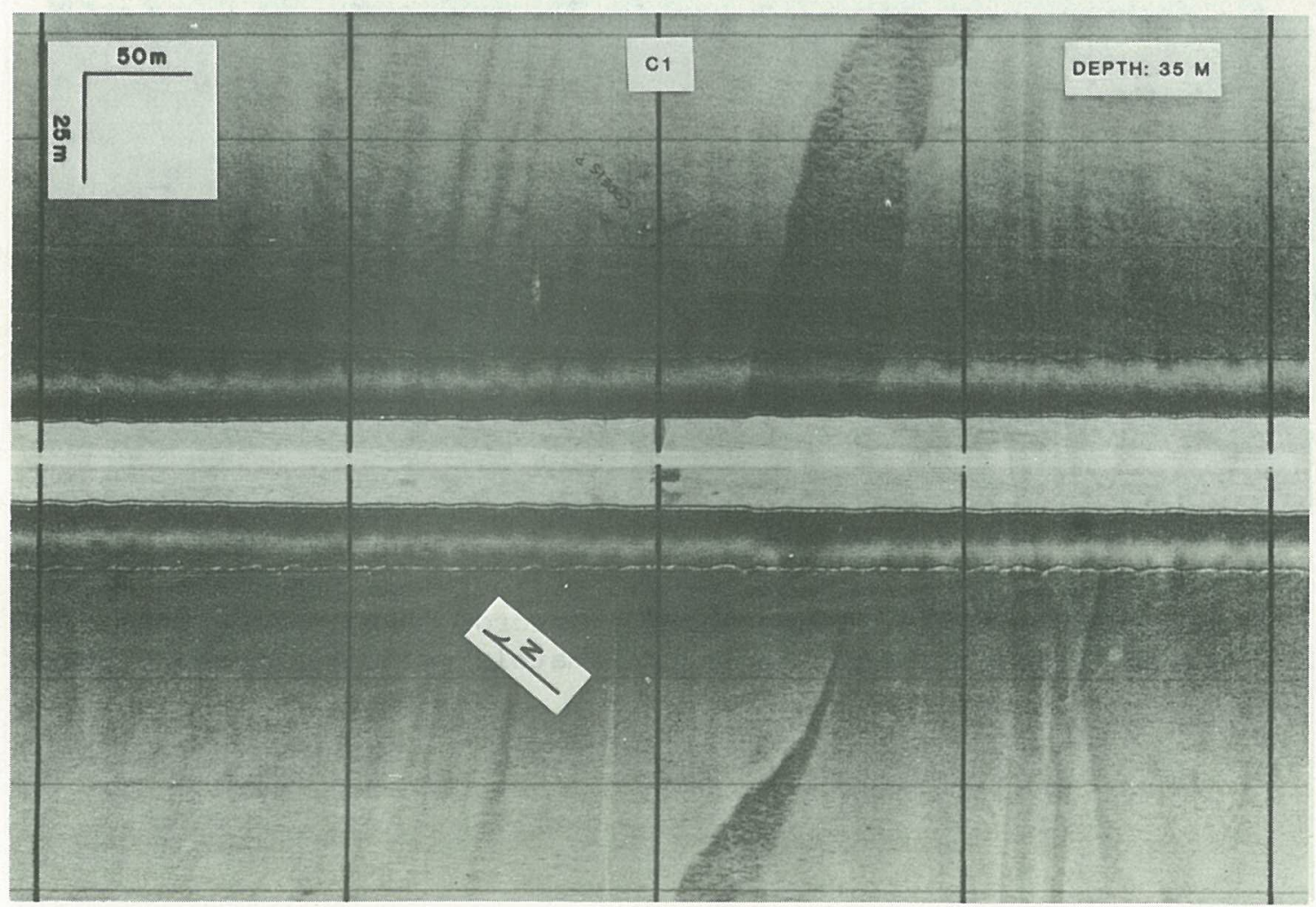

Fig. 7b. Wet-paper side scan sonar record taken near $\mathrm{Cl}$ with contact in upper center probably the GEOPROBE tripod. Erosional channel extends cross-shelf about $80-90 \mathrm{~m}$ to southeast of GEOPROBE. Apparent lineations running top to bottom at left of center in figure are artifacts of the recording paper. 


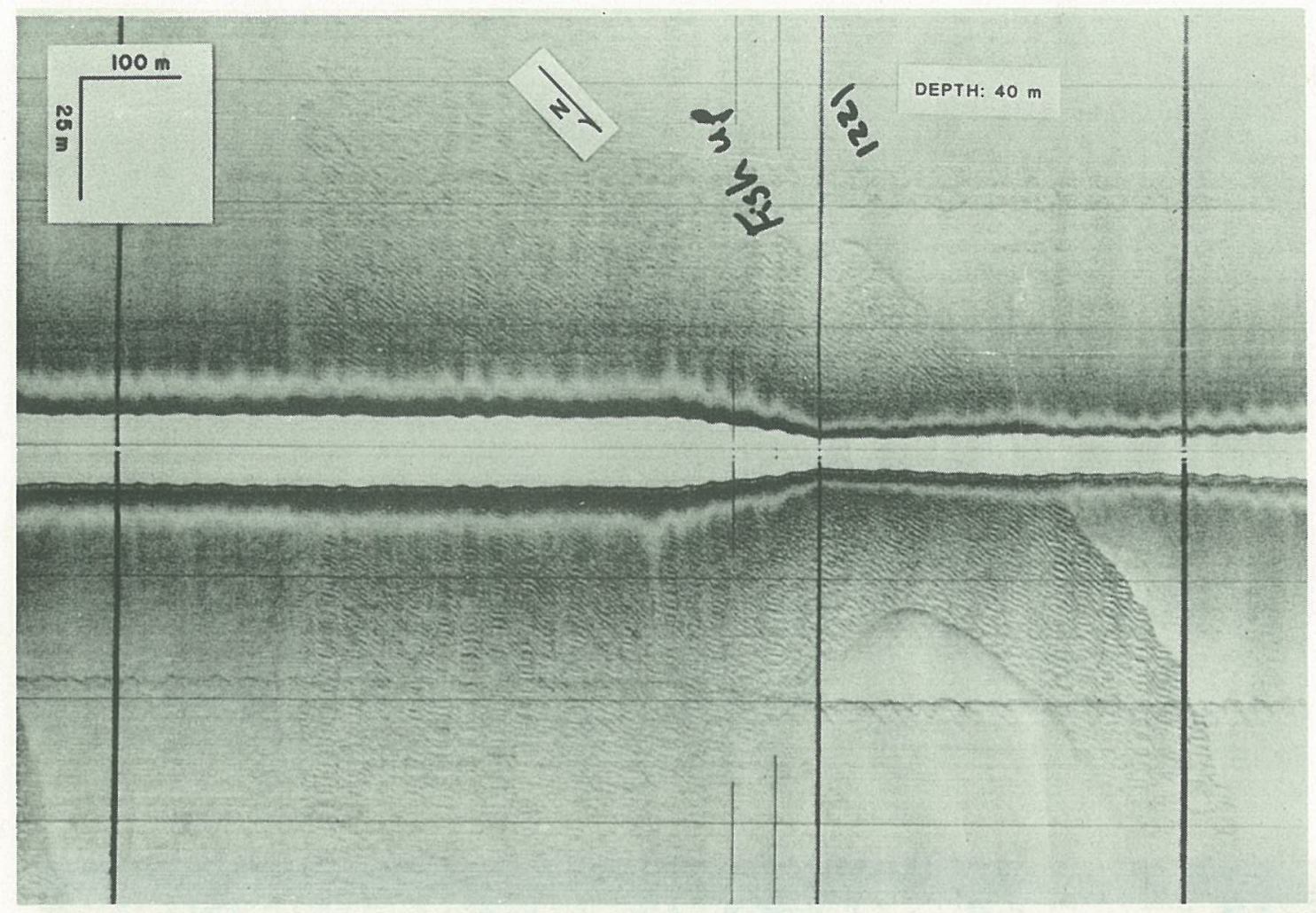

Fig. 8a. Wet-paper side-scan record showing inner shelf erosional channel with sand waves of about $1 \mathrm{~m}$ wave-length within channel. Sand wave crests are approximately parallel to bathymetry.

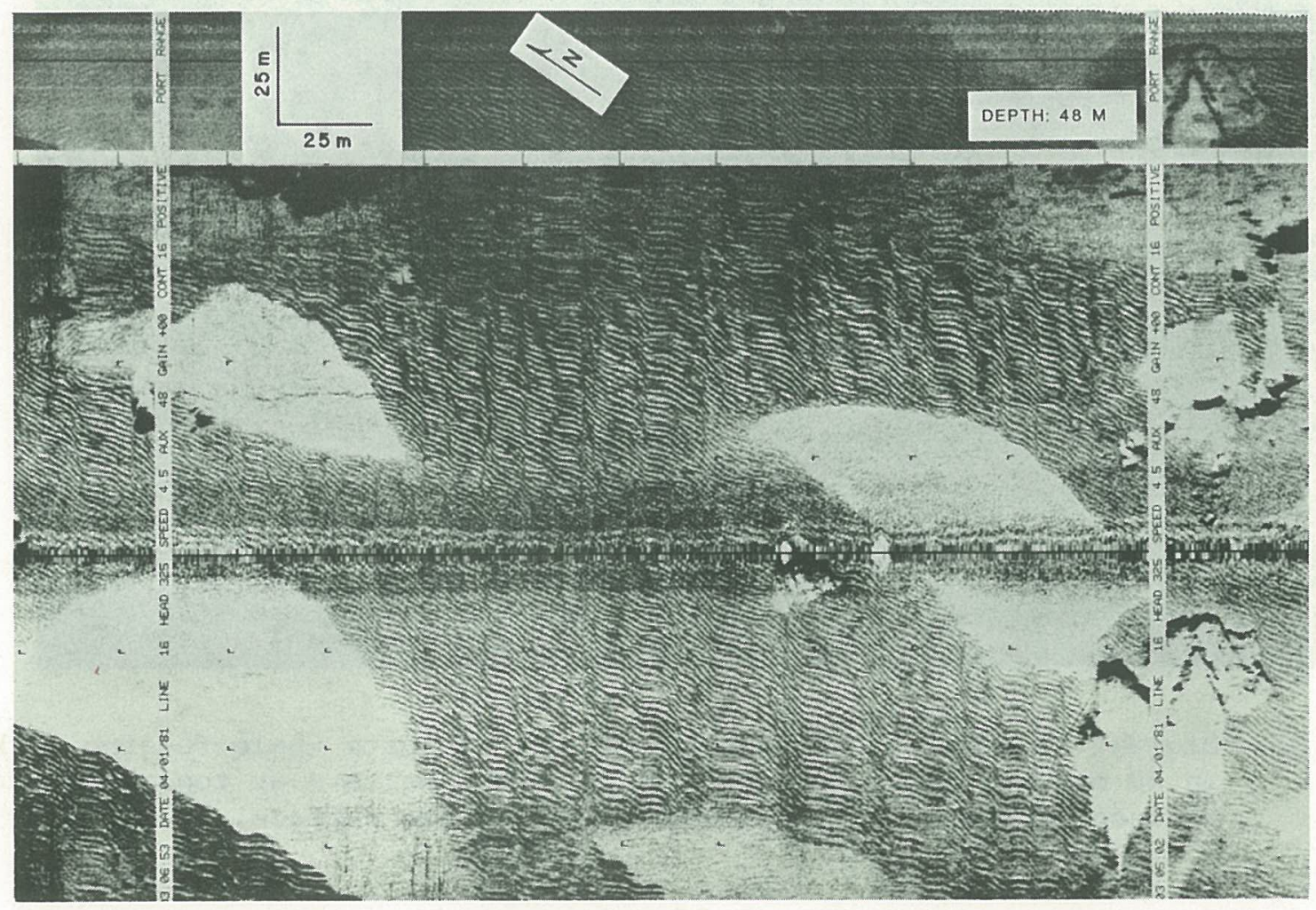

Fig. 8b. Digital side scan record showing well-developed sand waves on inner shelf near Stewarts Point. Rock outcrops and lighter patches (finer sand) are also seen. Herringbone pattern of crests is an artifact of towfish attitude fluctuations. Wave lengths of bedforms are about 1.7 meters. 

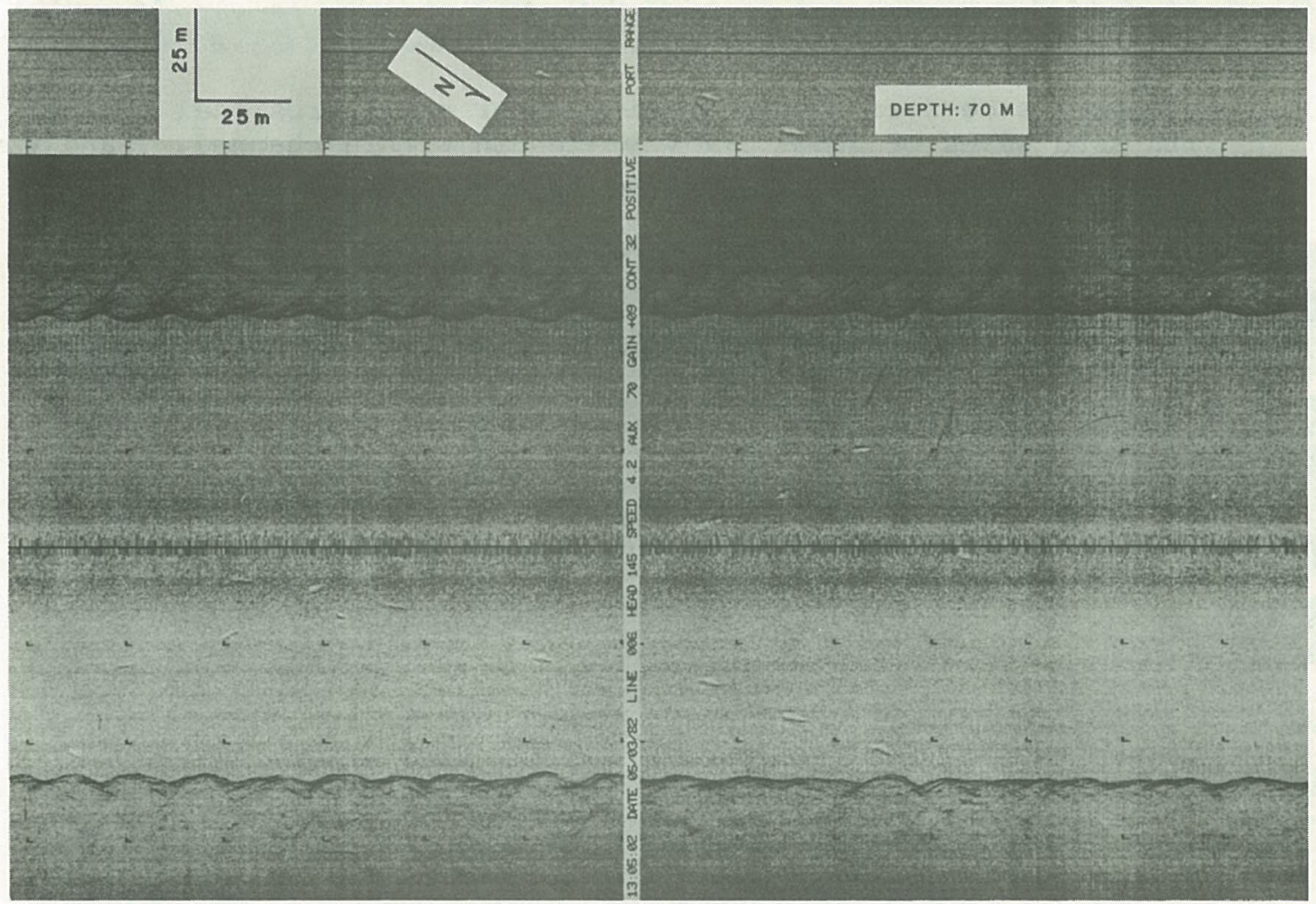

Fig. 8c. Digital side-scan sonar record showing elongate whale feeding marks in $70 \mathrm{~m}$ water depth in CODE region. Wavy pattern at top and bottom of record is a secondary reflection from sea surface. 


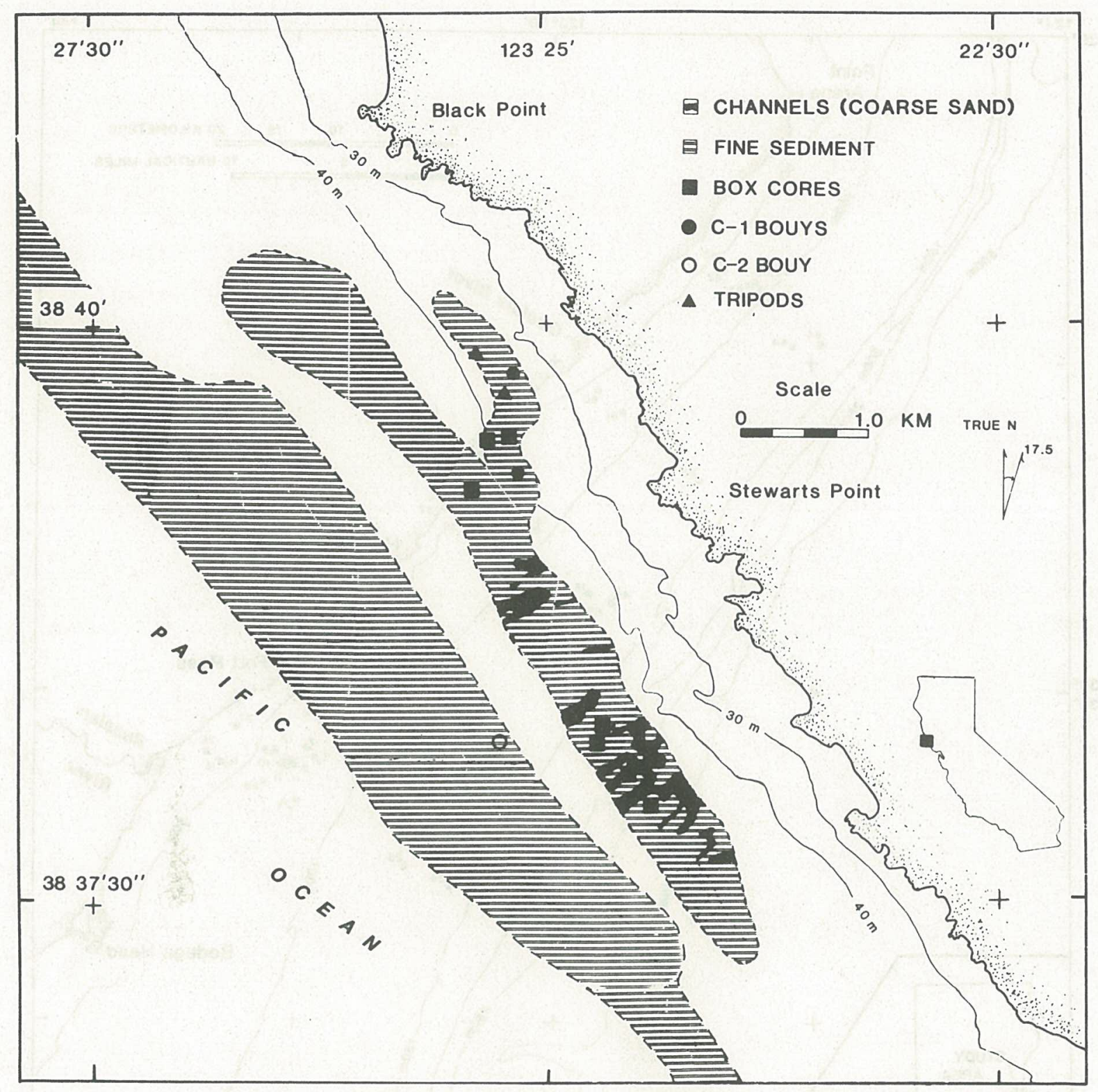

Fig. 9. Bottom features interpreted fron side scan records in CODE area. Sediment textures obtained from box core analyses. 


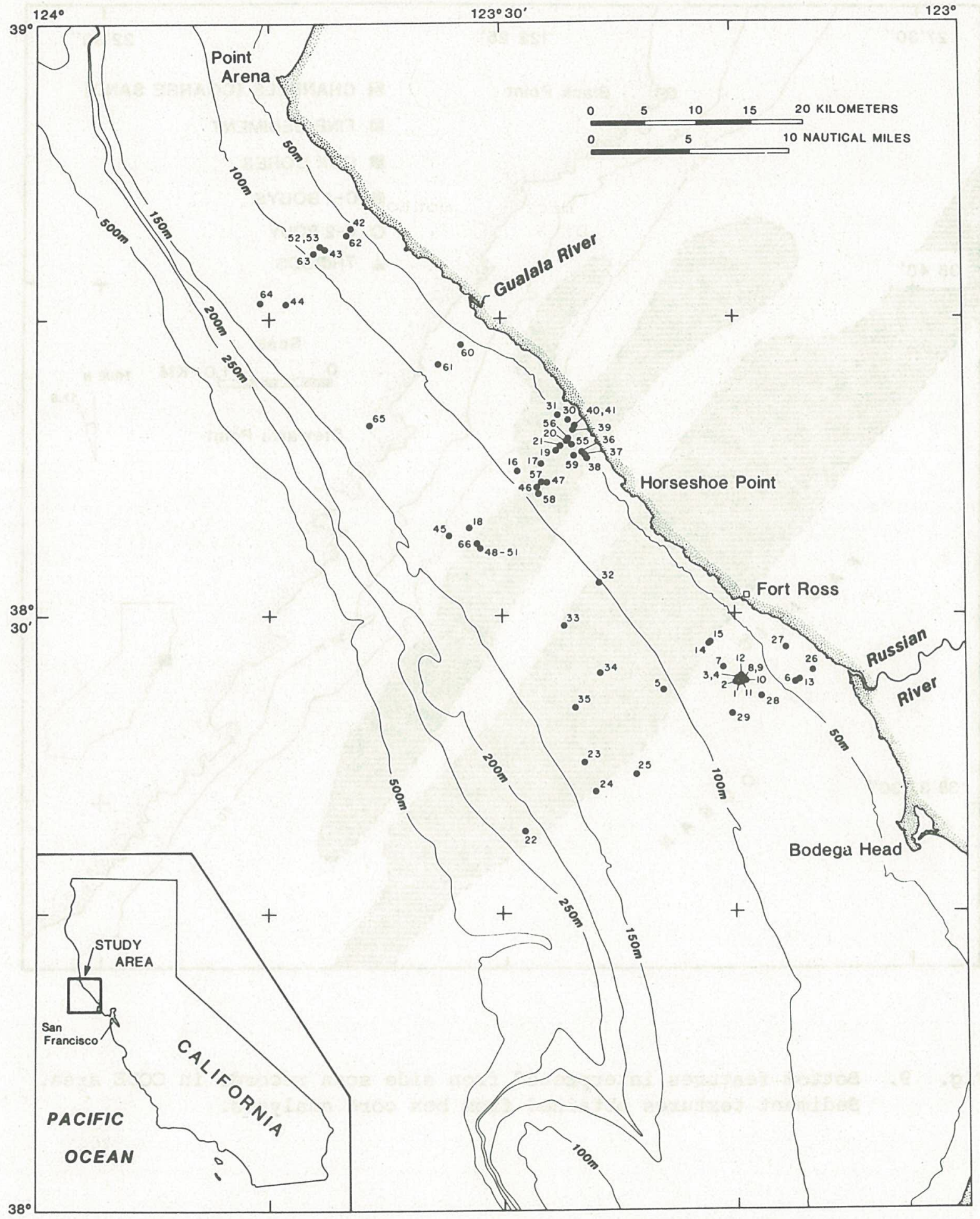

Fig. 10. Location of box core and grab samples taken by U.S.G.S. 


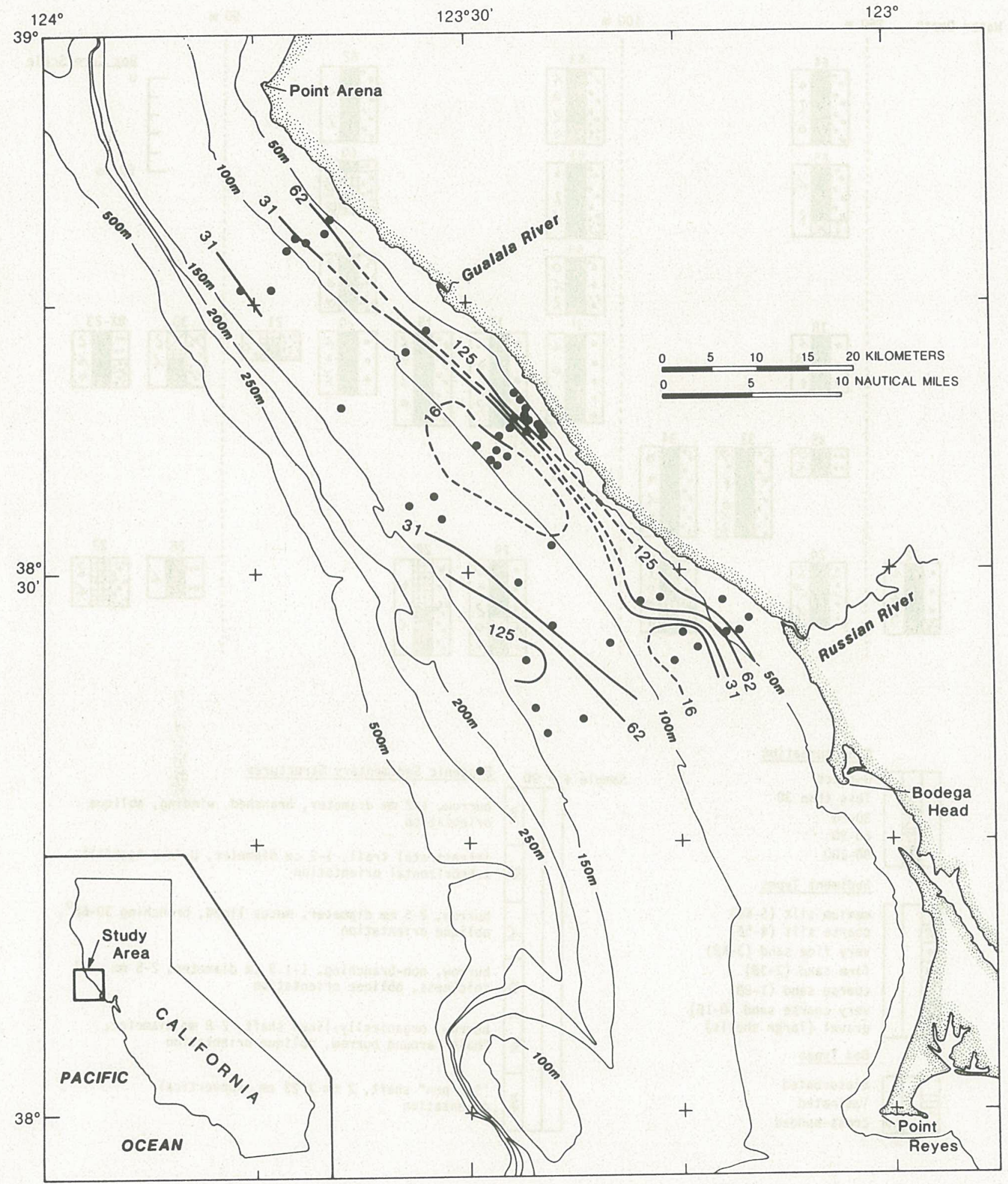

Fig. 11. Mean grain size (in microns) contour map based on bottom samples taken during pre-CODE and CODE. 


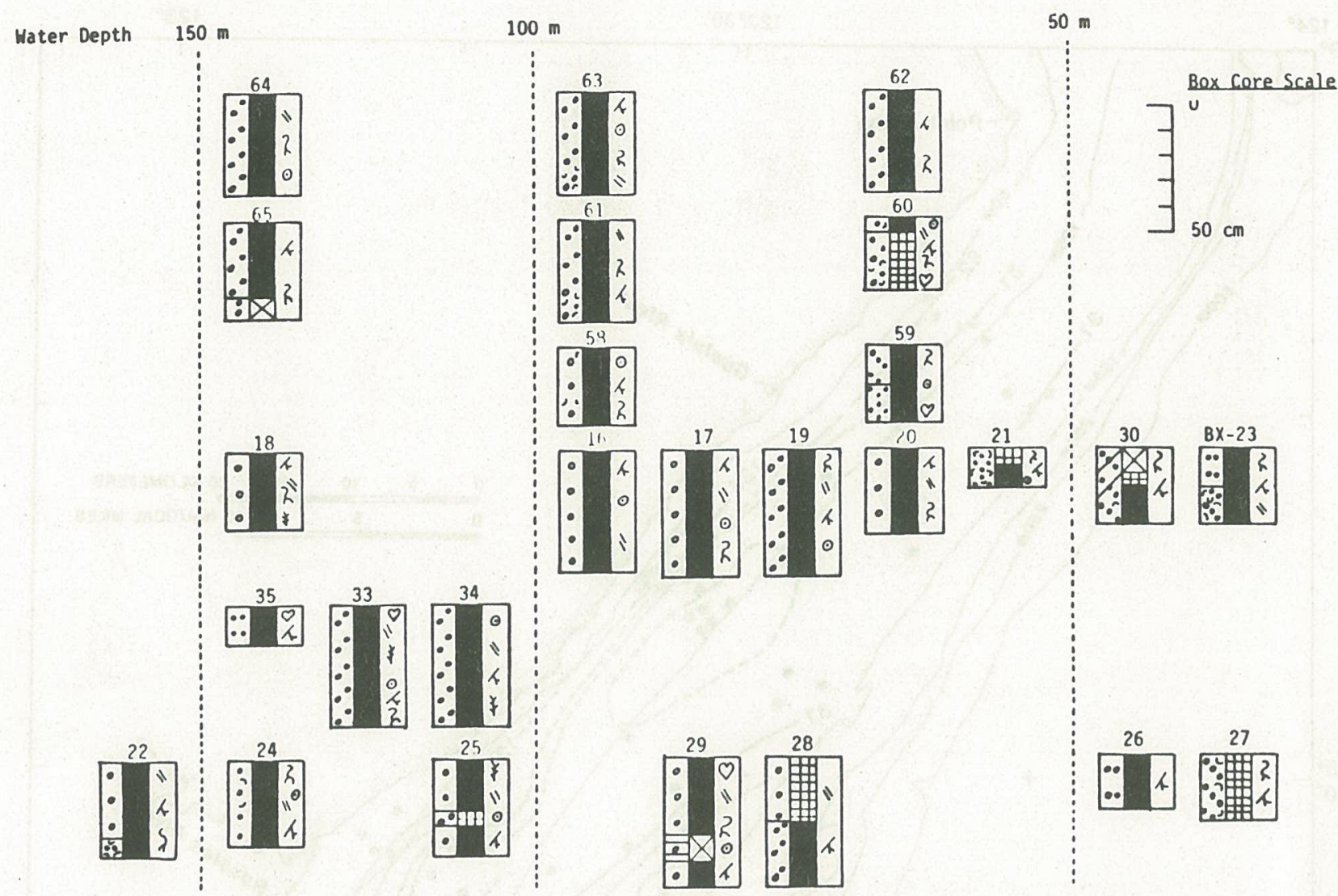

\% Bioturbation

侢 $\begin{aligned} & 0 \text {-trace } \\ & \text { less than } 30 \\ & 30-60 \\ & 60-90 \\ & 90-100\end{aligned}$

Sediment Types

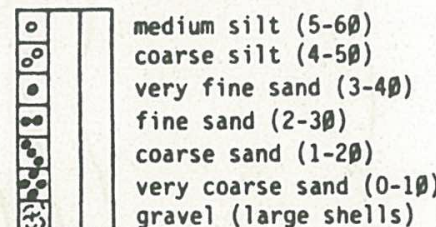

(large shells

Bed Types

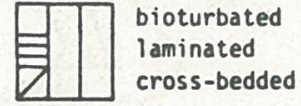

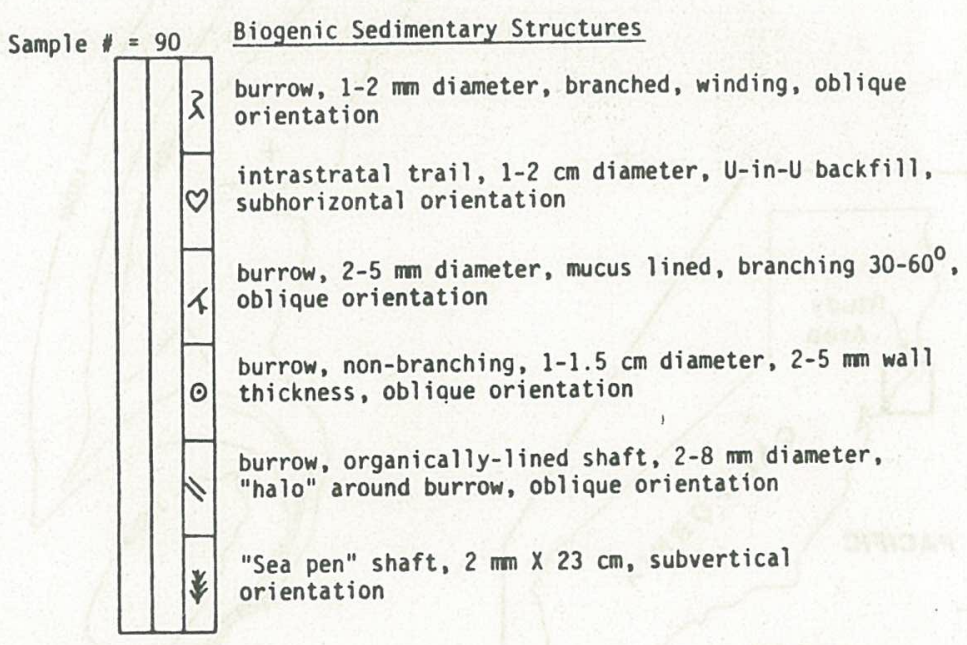

Fig. 12 Graphic representation of selected box core samples showing bioturbation, organism and sediment types. 


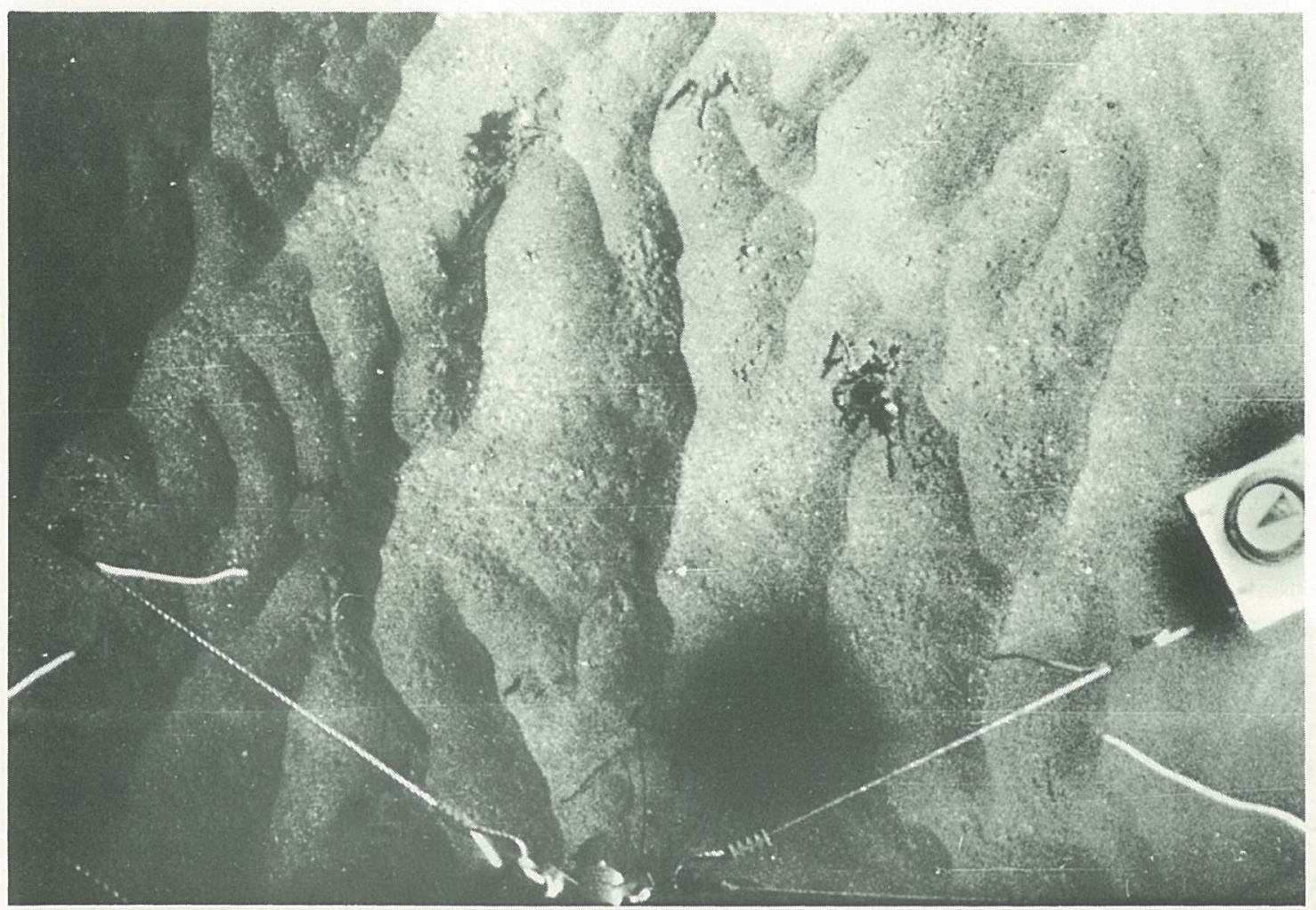

Fig. 13a. GEOPROBE photograph at Cl during CODE 1 showing sand ripples with white shelly materials in troughs. White compass face is $6.2 \mathrm{~cm}$ in diameter.

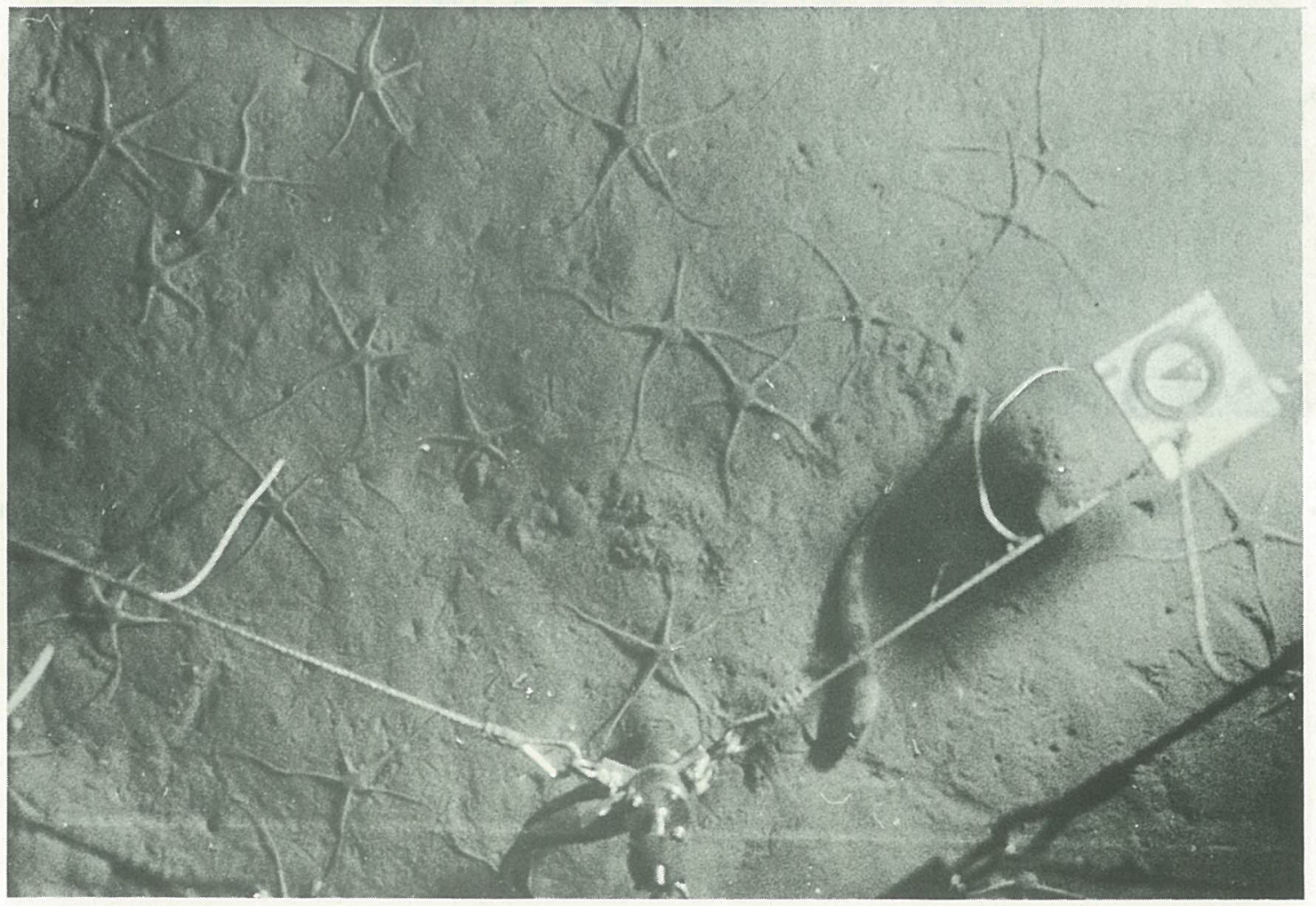

Fig. 13b. GEOPROBE photograph at C3 during CODE 1 showing brittle stars and animal marks on surface. Bottom pair of electromagnetic current meters are seen at bottom. White compass face is $6.2 \mathrm{~cm}$ in diameter. 


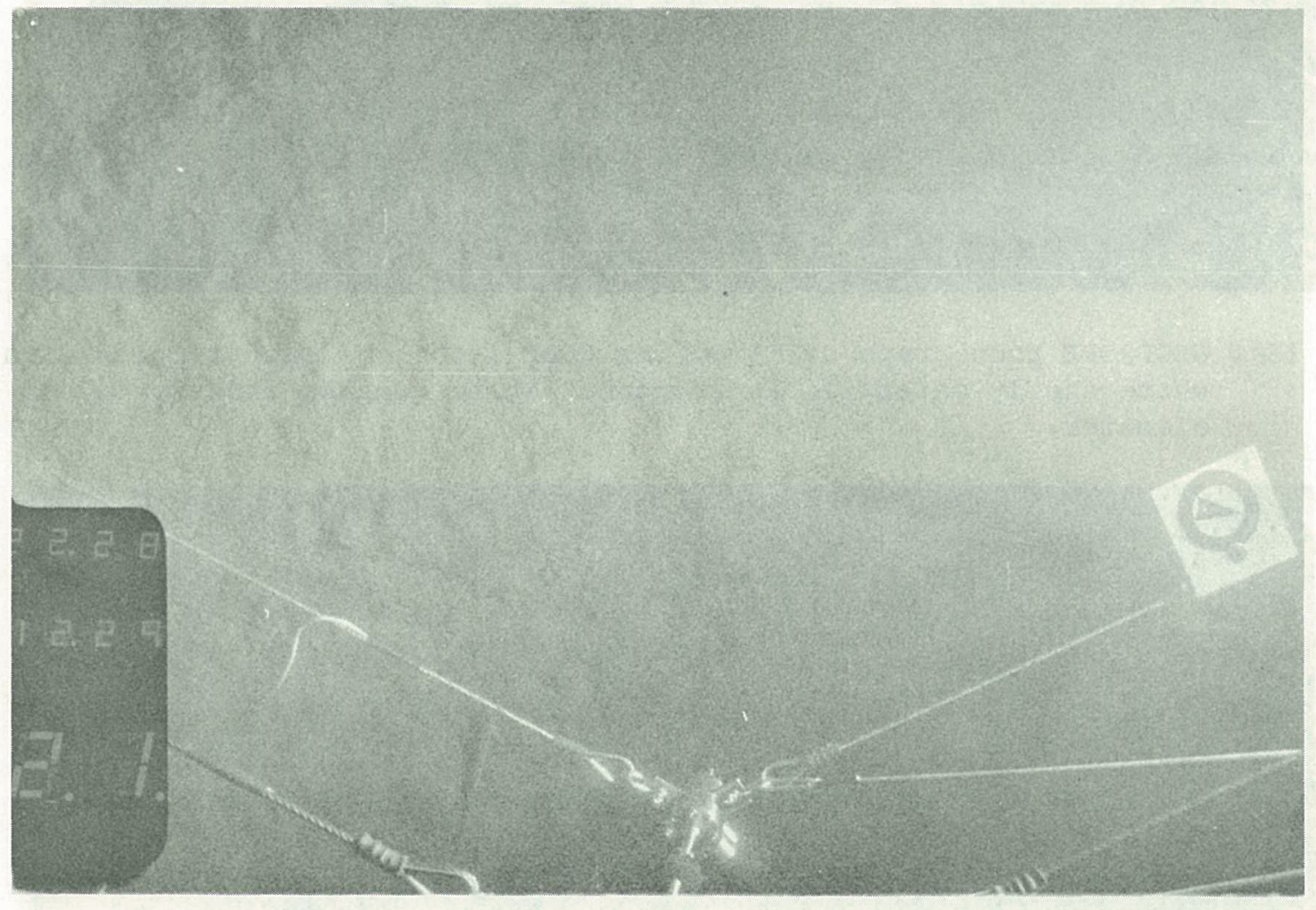

Fig. 13C. GEOPROBE photograph at C4 during CODE 2 showing flat, fine-grained bottom with animal markings. 
APPENDIX A - INFAUNAL COMMUNITY

A preliminary examination of the box core samples shows some differences in the infaunal communities at the Geoprobe locations (C-3, C-4, and REX). However, these samples and our limited analysis of them does not allow us to distinguish seasonal differences in the benthic community from spatial patterns related to the heterogeniety of depth and sediment type. The time series bottom photographs were examined to identify large animals missed by the box cores, and to observe the behavior of the other visible organisms. We have some concern about the effect of the flash of a light every 4 hours on the behavior of the animals.

The time series sequence of in situ photographs at $\mathrm{C}-3$ show the sediment surface to be highly perforated by burrows and the upper several centimeters to be routinely disturbed by the heart urchin, Brisaster latifrons. This large animal appears to alternately burrow under and plow through the sediment surface. The brittle stars Amphiodia urtica and Ophiura lutkenii appear occasionally on the surface, but the number collected in the box core indicates that a larger number is present under the sediment surface. As the body (disc) of the brittle star is generally positioned below the surface, the photographs may not detect the presence of their narrow but long arms (Table A), which are used for feeding on the sediment surface. The photos did show a permanent burrow (3-4 cm diameter) which was kept open throughout the 3 months of the study. The inhabitant was not seen but the possibilities among the large animals seen or collected at the site include a hagfish (Eptatretus sp.), octopus (Octopus sp.), or ghost shrimp (Callianasa sp.). The relative abundance of worm tubes and the presence of a tubed anemone, with tubes buried within the sediment and often extending above the surface, may stabilize the 
sediment below the highly bioturbated surface. In summary, the upper several centimeters of the sediment are highly and continuously bioturbated by large mobile echinoderms, with some stabilizing of the sub-surface sediments by tube-dwelling organisms.

The bottom photos at $\mathrm{C}-4$ showed little surface biological activity comparable to $\mathrm{C}-3$. This may, in part, reflect the inhibitory effect of the light flashing every 30 minutes at $\mathrm{C}-4$. The organisms collected in the box core showed a similar community to the one seen at $\mathrm{C}-3$, but there were considerably fewer organisms (Table A).

The REX station, on the other hand, contained a significantly greater abundance of burrowing polychaetes and a larger bivalve community. This more diverse and dense community probably reflects the closer proximity to the Russian River, a source of suspended organic material used as food. We would therefore expect the sediment surface to be disturbed to a degree at least equal to that at the CODE sites. 

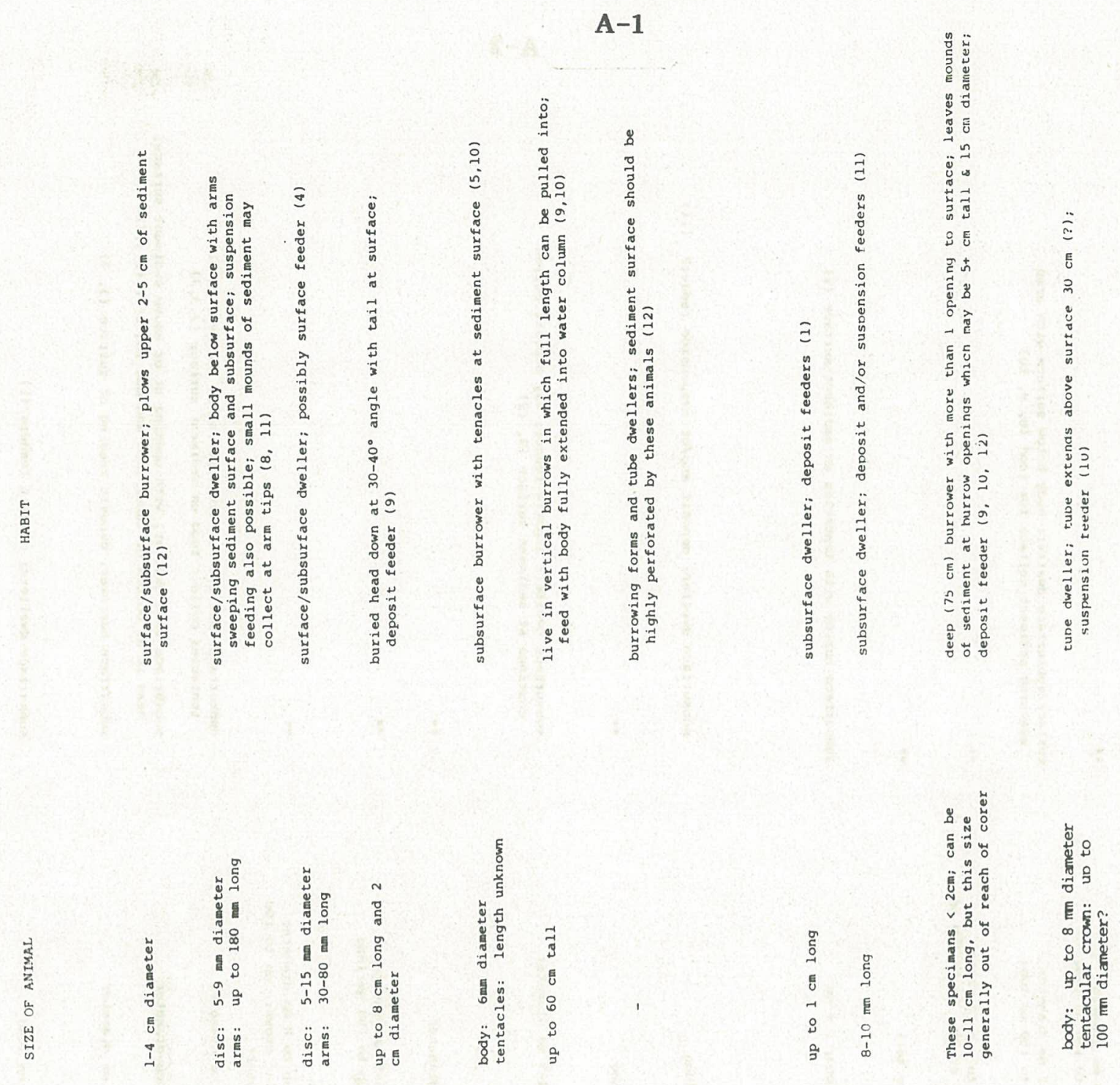

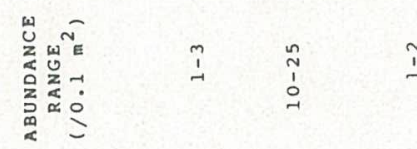

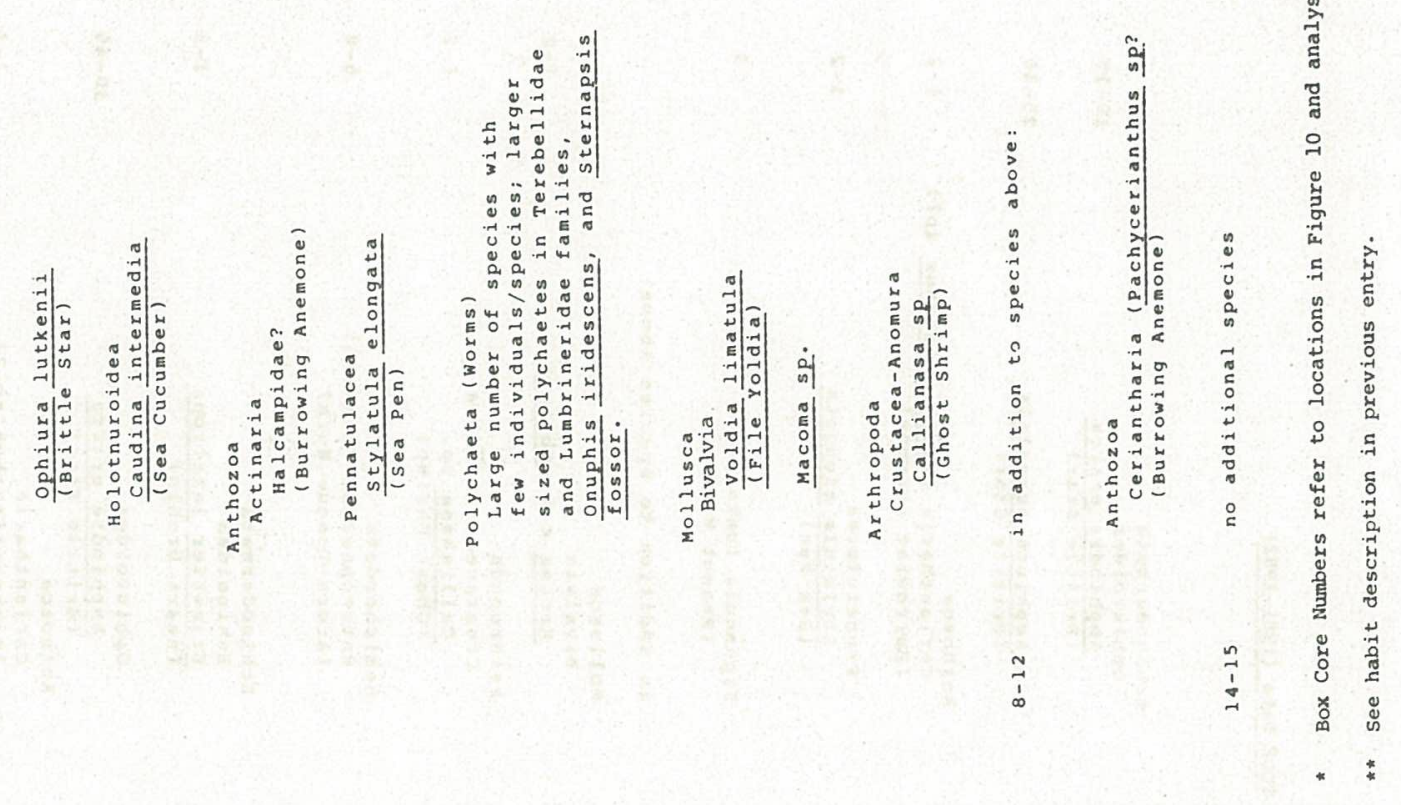




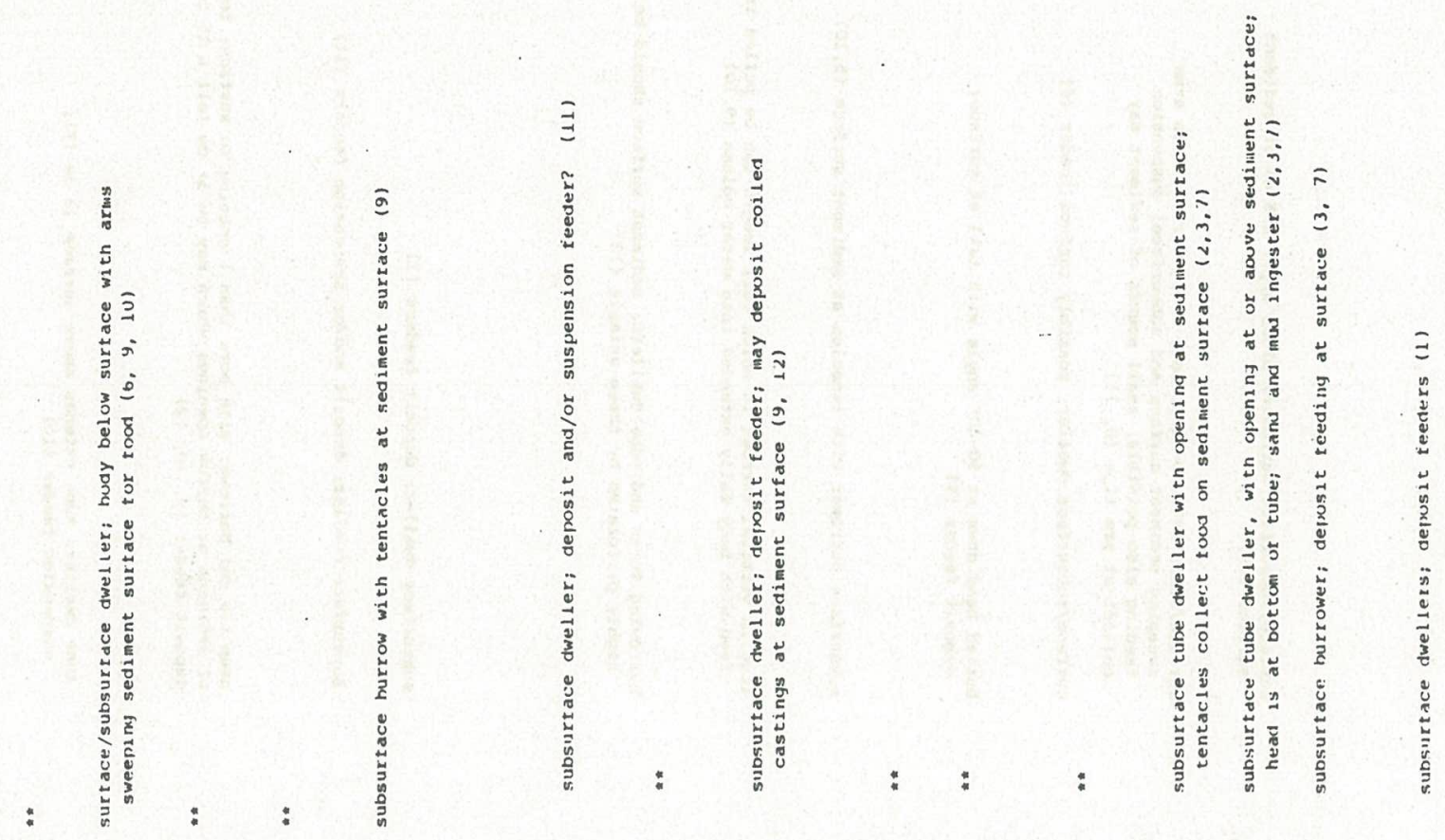

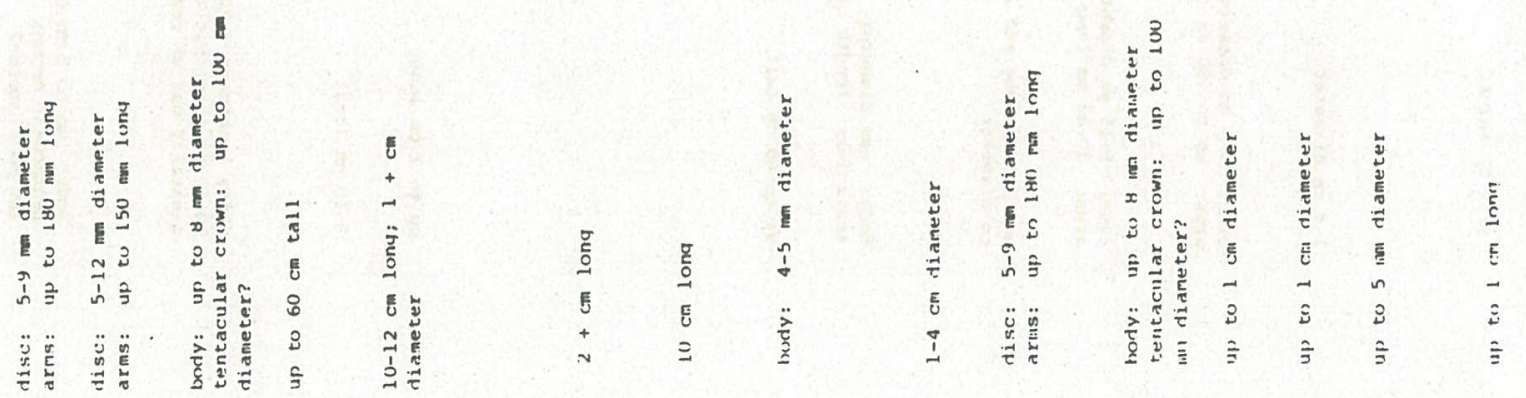

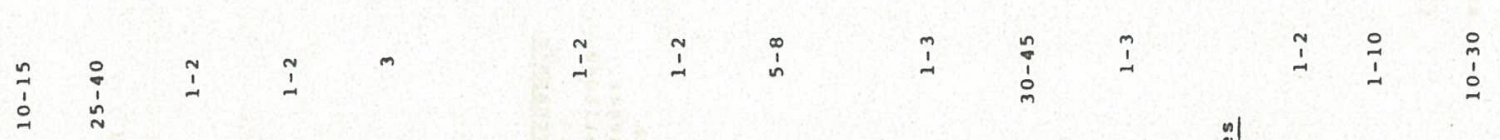

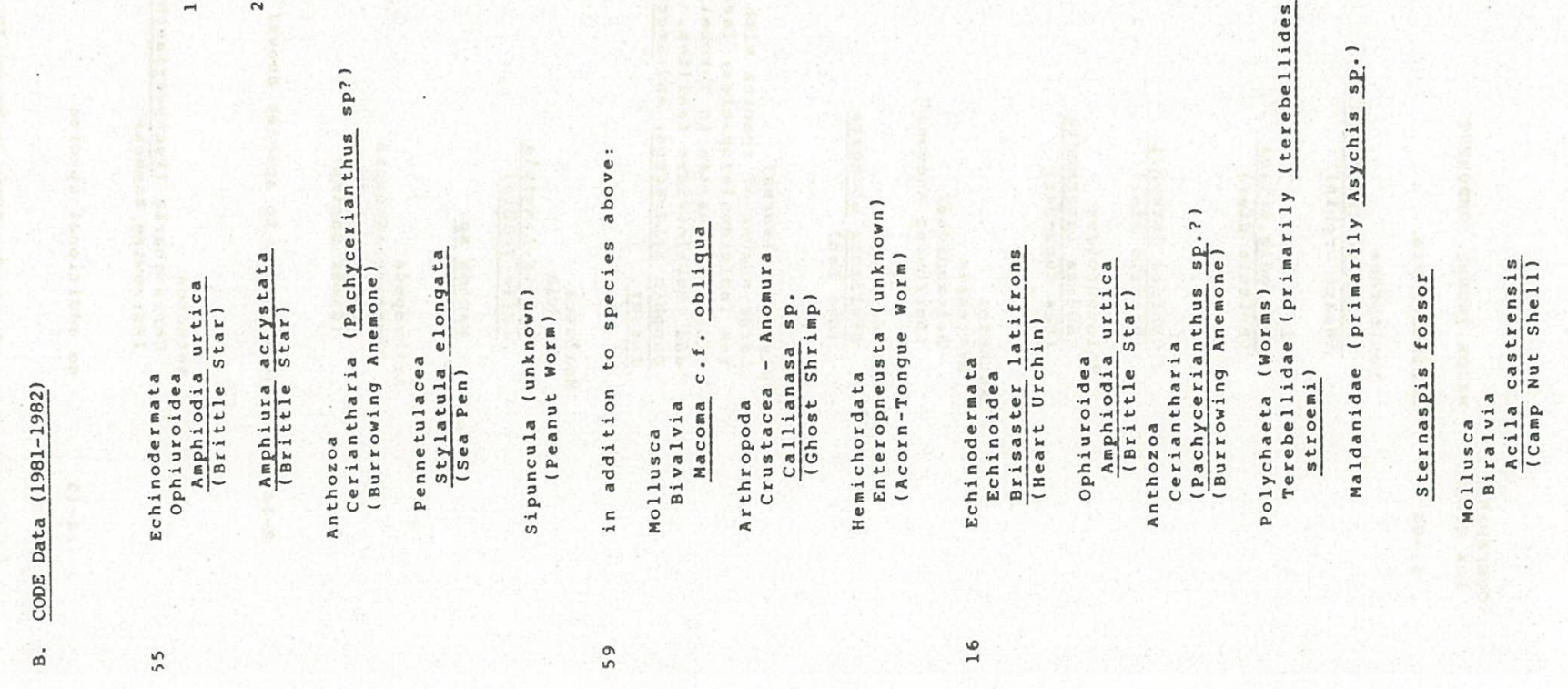




\section{A-3}
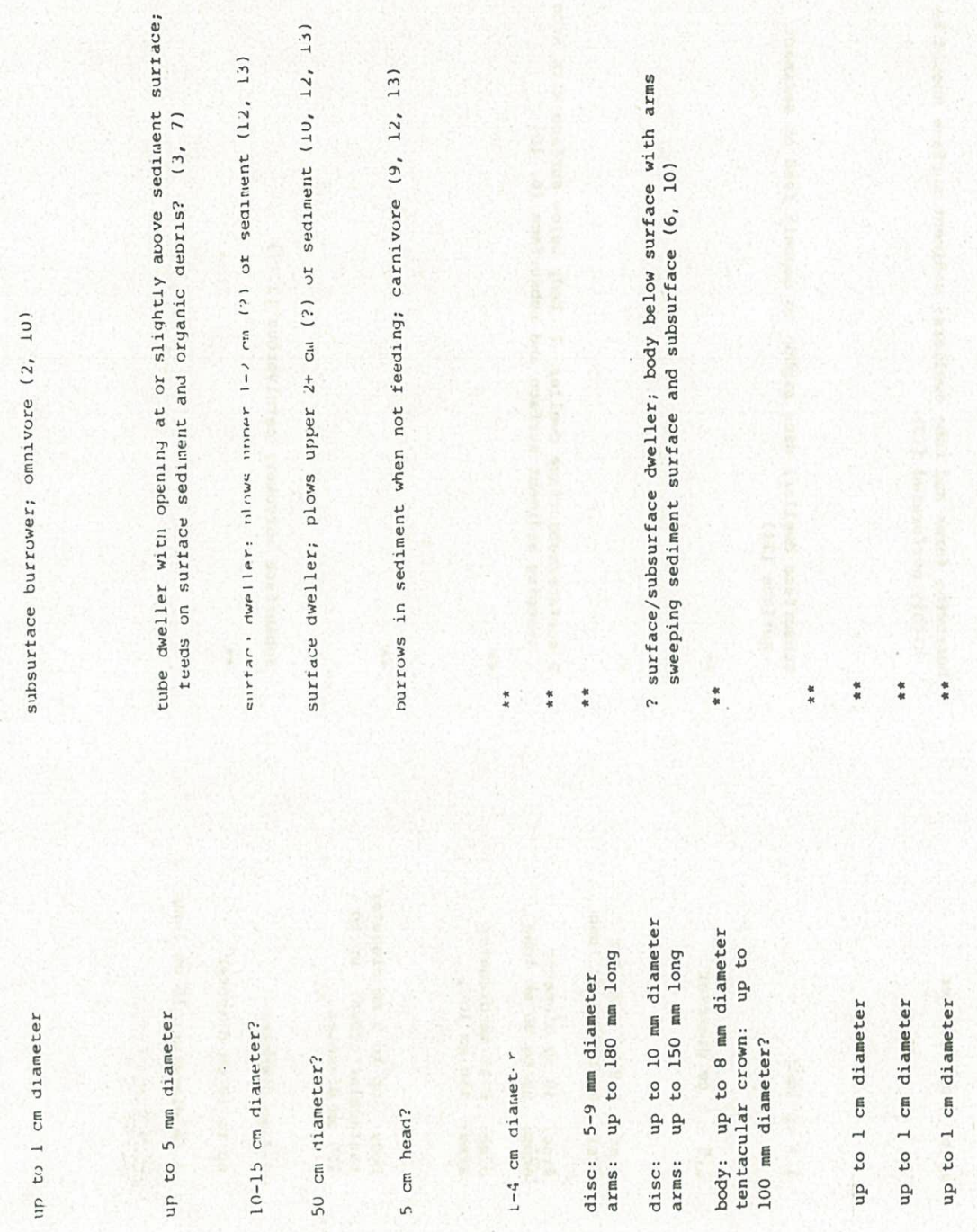

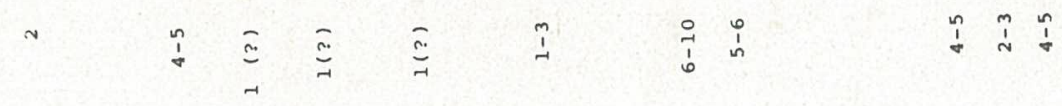

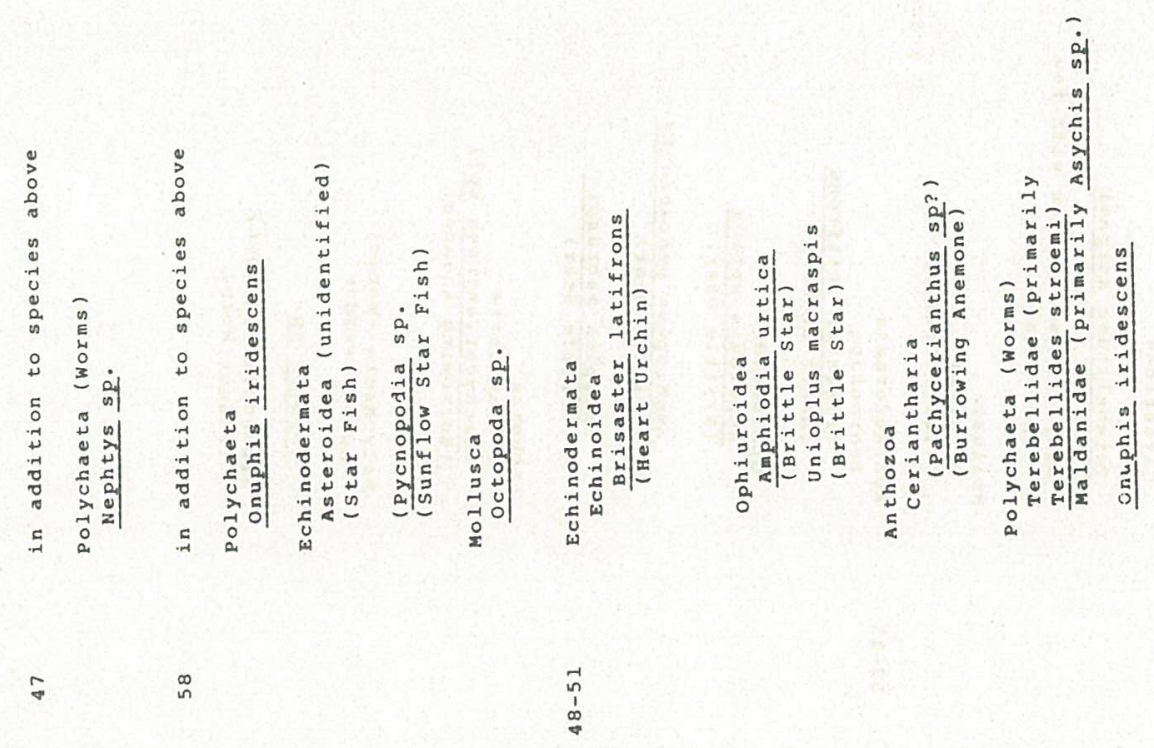



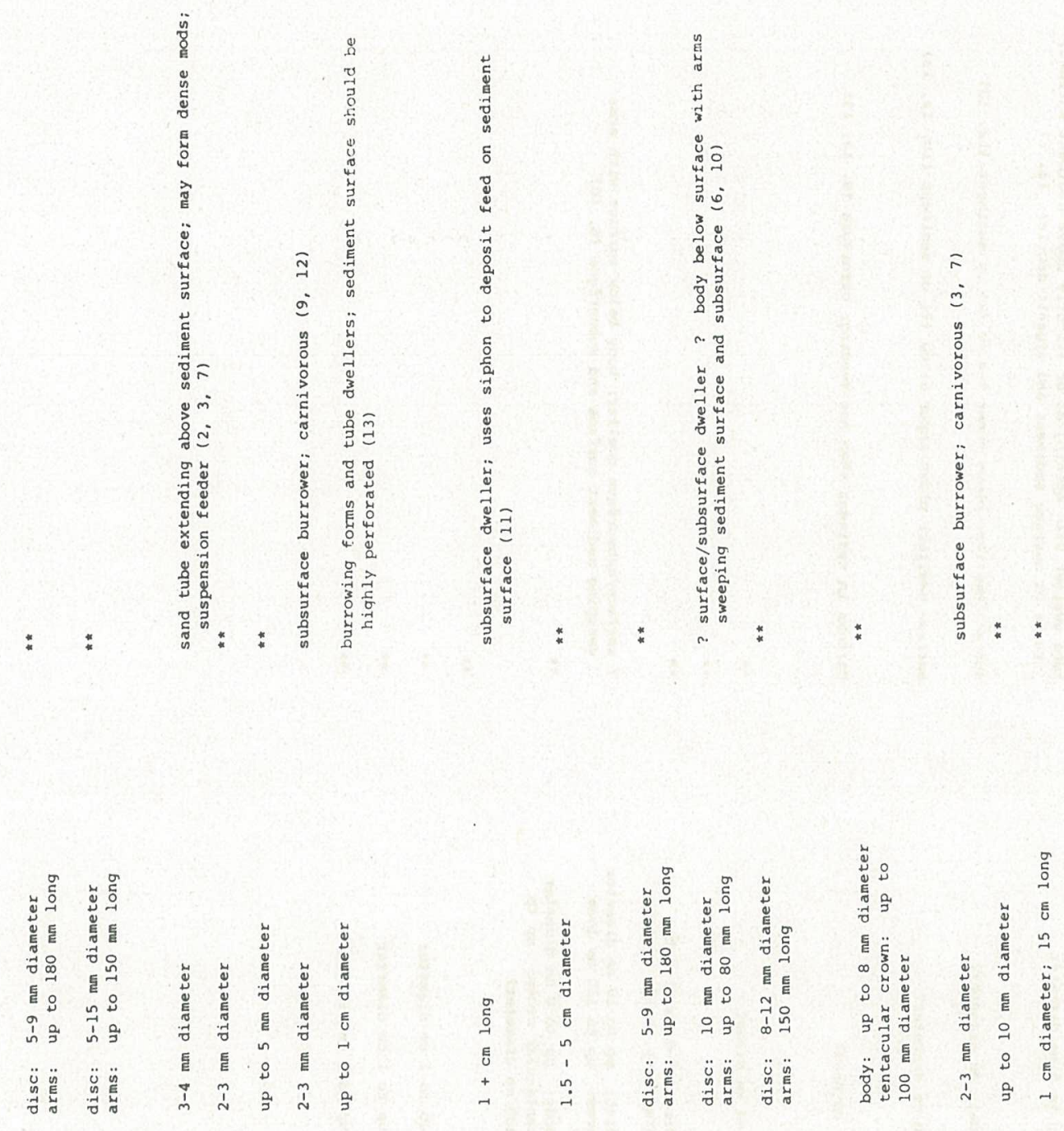

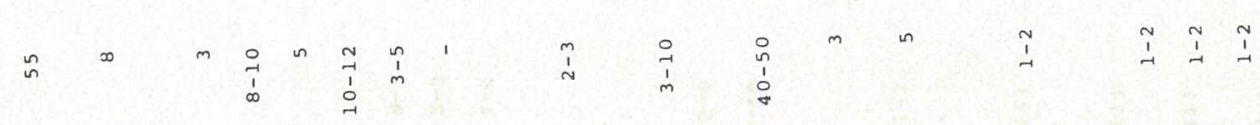

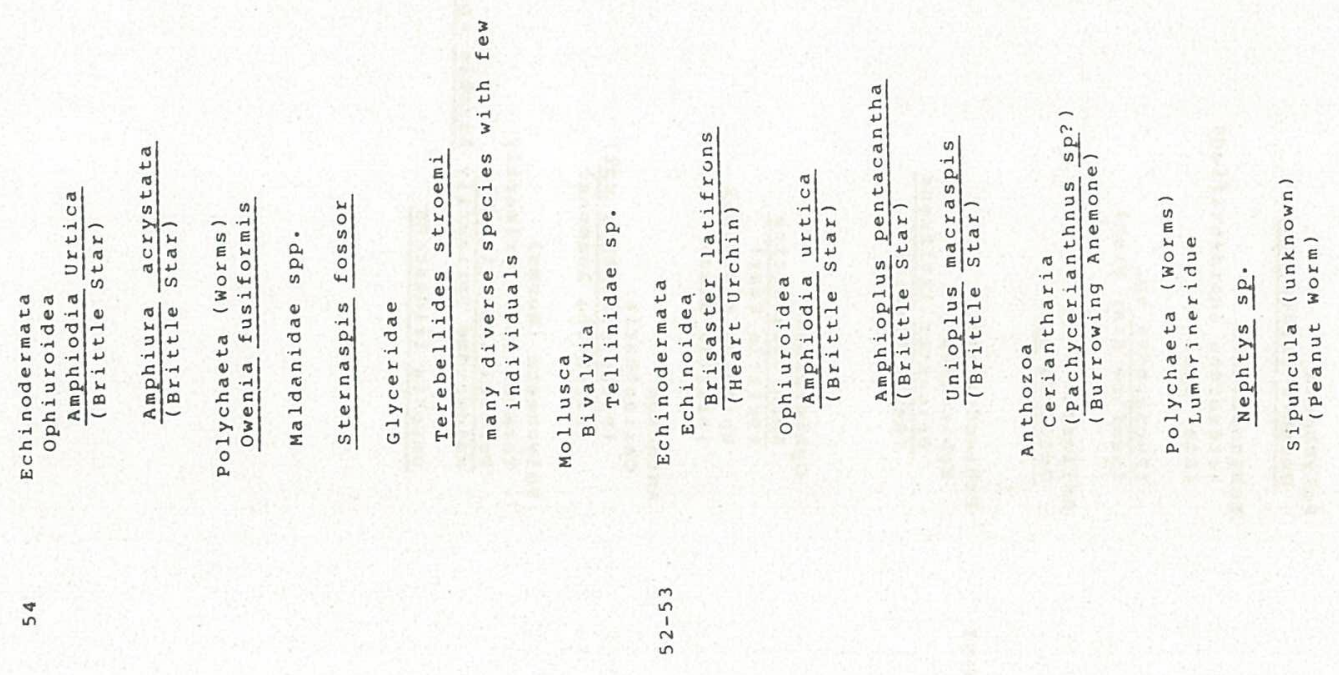




\begin{tabular}{|c|c|c|}
\hline $\begin{array}{l}\text { REPORT DOCUMENTATION } \\
\text { PAGE }\end{array}$ & $\begin{array}{l}\text { 1. REPORT NO. } \\
\text { WHOI-83-25 }\end{array}$ & 3. Recipient's Accession No. \\
\hline \multicolumn{2}{|c|}{$\begin{array}{l}\text { 4. Title and Subtitle } \\
\text { VARIABILITY OF SEA-FLOOR ROUGHNESS WITHIN THE COASTAL } \\
\text { OCEAN DYNAMICS EXPERIMENT (CODE) REGION }\end{array}$} & $\begin{array}{l}\text { 5. Report Date } \\
\text { August } 1983 \\
\text { 6. }\end{array}$ \\
\hline \multicolumn{2}{|c|}{$\begin{array}{l}\text { 7. Author(s) David A. Cacchione, David E. Drake, William D. Grant, } \\
\text { Albert J. Williams, III and George B. Tate }\end{array}$} & $\begin{array}{l}\text { 8. Performing Organization Rept. No. } \\
\text { WHOI- } 83-25\end{array}$ \\
\hline \multicolumn{2}{|c|}{$\begin{array}{l}\text { 9. Performing Organization Name and Address } \\
\text { Woods Hole Oceanographic Institution, Woods Hole, MA } 02543 \\
\text { and } \\
\text { United States Geological Survey, Menlo Park, CA } 94040\end{array}$} & $\begin{array}{l}\text { 10. Project/Task/Work Unit No. } \\
\text { 11. Contract(C) or Grant(G) No. } \\
\text { (c) OCE } 80-14938 \\
\text { (G) OCE } 80-14941\end{array}$ \\
\hline $\begin{array}{l}\text { 12. Sponsoring Organization Name } \\
\text { The National Science } \\
\text { and } \\
\text { United States Geolog }\end{array}$ & $\begin{array}{l}\text { Foundation } \\
\text { ical survey }\end{array}$ & $\begin{array}{l}\text { 13. Type of Report \& Period Covered } \\
\text { 14. Technical }\end{array}$ \\
\hline
\end{tabular}

15. Supplementary Notes

This report should be cited as: Woods Hole Oceanog. Inst. Tech. Rept. WHOI-83-25.

16. Abstract (Limit: 200 words)

This report summarizes the geological and biological data taken on the northern California

Continental Shelf before and during the Coastal Ocean Dynamics Experiment (CODE) by the principal investigators of the bottom stress/bottom boundary layer component of CODE (D. Cacchione, D. Drake, USGS and W. Grant, A. Williams, WHOI). The report concentrates on a description of the seafloor relief that likely influences the near bottom flow field at the CODE site, and that significantly affects bottom stress estimates. The general physical characteristics of the CODE site, the macro- and micro- physiography, sediment distribution and discharge of the larger coastal rivers are described. On a large scale the shelf is relatively narrow, diminishing in width from SE to NW with an average cross-shelf gradient of 0.004 . The outer shelf is flat and floored by relict sand to the south and sandy-silt to the north. The central shelf is also flat and is floored by silt. The inner shelf is sandy with irregularly spared submerged out crops. On the small scale, the central shelf surface is highly bioturbated consisting of animal tracks, mounds and furrows. The inner shelf is covered with oscillatory ripple marks.

17. Document Analysis a. Descriptors

1. Bottom roughness

2. Coastal Ocean Dynamics Experiment

3. Geological and Biological Data

b. Identifiers/Open-Ended Terms

c. COSATI Field/Group

18. Availability Statement

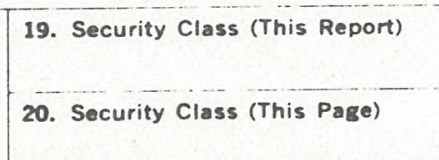

19. Security Class (This Report)
20. Security Class (This Page)

$+\ldots$

(See ANSI-Z39.18)
21. No. of Pages 50

22. Price 
